\title{
Nucleophilic Additions of Trimethylsilyl Cyanide to Cyclic Oxocarbenium Ions: Evidence for the Loss of Stereoselectivity at the Limits of Diffusion Control
}

\author{
Siddhartha R. Shenoy, Deborah M. Smith, and K. A. Woerpel* \\ Department of Chemistry \\ University of California, Irvine \\ Irvine, CA 92697-2025
}

Supporting Information

\section{Contents:}

I. General Experimentals $\quad$ S-1

II. $\quad$ Synthesis of Six-Membered Ring Compounds $\quad$ S-1

III. Synthesis of Five-Membered Ring Compounds $\quad$ S-3

IV. Synthesis of Solid-Supported Compounds $\quad$ S-5

V. General Procedures for Competition Experiments $\quad$ S-6

$\begin{array}{lll}\text { VI. Stereochemical Proofs } & \text { S-7 }\end{array}$

VII. References $\quad$ S-9

$\begin{array}{lr}\text { VIII. Analytical Data } & \text { S-10 }\end{array}$

\section{General Experimentals}

${ }^{1} \mathrm{H}$ NMR and ${ }^{13} \mathrm{C}$ NMR spectra were recorded at ambient temperature at $500 \mathrm{MHz}$ and $400 \mathrm{MHz}$ and $125 \mathrm{MHz}$, respectively, using a Bruker DRX 500 or DRX 400 spectrometers. The data are reported as follows: chemical shift in ppm from internal tetramethylsilane on the $\delta$ scale, multiplicity ( $\mathrm{br}=$ broad, $\mathrm{s}=$ singlet, $\mathrm{d}=$ doublet, $\mathrm{t}=$ triplet, $\mathrm{q}=$ quartet, $\mathrm{m}=$ multiplet), coupling constants $(\mathrm{Hz})$, and integration. Infrared (IR) spectra were obtained using a MIDAC Prospect FT-IR spectrometer. High resolution mass spectra were acquired on a VG Analytical 7070E or Fisons Autospec spectrometer, and were obtained by peak matching. Microanalyses were performed by Atlantic Microlab, Atlanta, GA. Analytical gas-liquid chromatography (GC) analyses were performed on a Hewlett Packard 5890 Level 4 Chromatograph, equipped with a split-mode injection system and a flame ionization detector. A fused silica capillary column (30 m x $0.32 \mathrm{~mm}$ ) wall-coated with DB-1 (J \& W Scientific) was used with helium as the carrier gas (16 psi column head pressure). Liquid chromatography was performed using forced flow (flash chromatography) of the indicated solvent system on EM Reagents silica gel $\left(\mathrm{SiO}_{2}\right) 60$ (230-400 mesh). All reactions were carried out under an atmosphere of nitrogen in glassware that had been flame-dried under vacuum $(0.05 \mathrm{~mm} \mathrm{Hg})$. Unless otherwise noted, all reagents were commercially obtained and, where appropriate, purified prior to use. THF, $\mathrm{Et}_{2} \mathrm{O}$, and $\mathrm{CH}_{2} \mathrm{Cl}_{2}$ were dried by filtration through alumina. ${ }^{1}$

\section{Synthesis of Six-Membered Ring Compounds}

The synthesis of acetal $\mathbf{1}$ and allylated product 19 have previously been reported. ${ }^{2}$

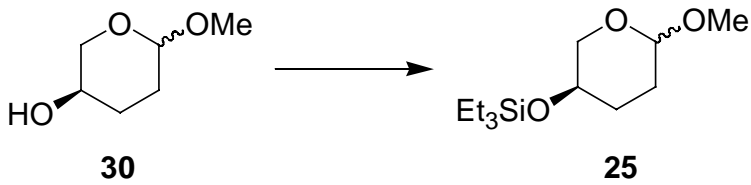

4-(Triethylsilyloxy)-1-methoxytetrahydropyran (25). To a solution of the alcohol 30 (1.5 g, 12 mmol) $)^{3}$ and 4-N,Ndimethylaminopyridine $(0.17 \mathrm{~g}, 1.4 \mathrm{mmol})$ in $5.0 \mathrm{~mL}$ of $\mathrm{CH}_{2} \mathrm{Cl}_{2}$ was added $\mathrm{Et}_{3} \mathrm{~N}(4.2 \mathrm{~mL}, 30 \mathrm{mmol})$ at $0{ }^{\circ} \mathrm{C}$. After $2 \mathrm{~min}$, the cooled solution was treated with chlorotriethylsilane $(1.8 \mathrm{~mL}, 11 \mathrm{mmol})$ dropwise by syringe. The reaction mixture was stirred overnight, warming gradually to room temperature. After $18 \mathrm{~h}$, distilled $\mathrm{H}_{2} \mathrm{O}(5.0 \mathrm{~mL})$ was added to dissolve the white precipitate that had formed. The layers were separated, and the aqueous layer was extracted with $\mathrm{Et}_{2} \mathrm{O}(3 \times 10 \mathrm{~mL})$. The combined organic layers were washed sequentially with aqueous $\mathrm{HCl}(1 \mathrm{~N}, 25 \mathrm{~mL})$, saturated aqueous $\mathrm{NaHCO}_{3}(25 \mathrm{~mL})$, and brine $(25 \mathrm{~mL})$, dried over $\mathrm{Na}_{2} \mathrm{SO}_{4}$, filtered, and concentrated in vacuo to afford a dark yellow oil. The resulting oil was purified by column chromatography (1:9 EtOAc/hexanes) to afford the product 25 (3:1 mixture of anomers) as a colorless oil $(1.7 \mathrm{~g}, 62 \%)$ : ${ }^{1} \mathrm{H}$ NMR $\left(400 \mathrm{MHz}^{4} \mathrm{CDCl} 3\right) \delta$ 4.55 (dd, $J=3.1,1.7,0.3 \mathrm{H}), 4.47$ (dd, $J=5.2,2.4,1 \mathrm{H}$ ), 3.85 (ddd, $J=11.4,3.2,0.9,1 \mathrm{H}$ ), $3.75-3.65$ (m, $1.3 \mathrm{H}), 3.49-3.46$ (m, $0.6 \mathrm{H}$ ), 3.48 (s, 3H), 3.34 (s, 0.9H), 3.31 (dd, $J=11.0,6.2,1 \mathrm{H}), 2.05-1.90$ (m, 2H), $1.84-1.77$ (m, 0.3H), 1.74 (dd, $J=10.8,3.7$, $0.3 \mathrm{H}), 1.71-1.60(\mathrm{~m}, 0.3 \mathrm{H}), 1.55-1.45(\mathrm{~m}, 2 \mathrm{H}), 1.25-1.15(\mathrm{~m}, 0.3 \mathrm{H}), 0.95$ (t, $J=7.8,11.7 \mathrm{H}), 0.6$ (q, $J=7.8,6 \mathrm{H}), 0.58$ (q, $J=7.9$, $1.8 \mathrm{H}) ;{ }^{13} \mathrm{C}$ NMR (125 MHz, $\left.\mathrm{CDCl}_{3}\right) \delta$ 100.7, 98.0, 67.9, 66.5, 65.9, 65.6, 55.8, 55.0, 29.0, 28.9, 27.6, 7.0, 5.0, 4.9; IR (thin film) 2954, 
2873, 1459, 1220, 1018, $758 \mathrm{~cm}^{-1}$; HRMS (GC-MS, EI) m/ z calcd for $\mathrm{C}_{12} \mathrm{H}_{26} \mathrm{O}_{3} \mathrm{SiNa}(\mathrm{M}+\mathrm{Na})^{+}$269.1549, found 269.1546. Anal. Calcd for $\mathrm{C}_{12} \mathrm{H}_{26} \mathrm{O}_{3} \mathrm{Si}$ : C, 58.49; H, 10.63. Found: C, 58.64; H, 10.87.

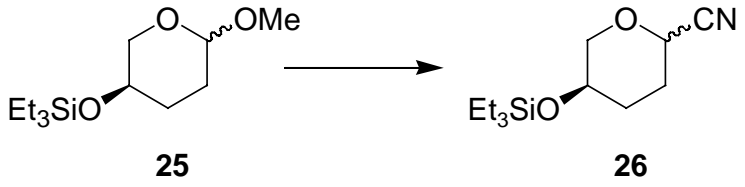

4-(Triethylsilyloxy)-1-cyanotetrahydropyran (26). A solution of methyl acetal 25 (0.100 g, $0.41 \mathrm{mmol})$ in $\mathrm{CH}_{2} \mathrm{Cl}_{2}(2.0 \mathrm{~mL})$ was cooled to $-78{ }^{\circ} \mathrm{C}$ and treated with $\mathrm{Me}_{3} \mathrm{SiCN}(0.20 \mathrm{~mL}, 1.5 \mathrm{mmol})$. To the cooled $\left(-78{ }^{\circ} \mathrm{C}\right)$ solution was added $\mathrm{BF}_{3} \cdot \mathrm{OEt}_{2}(0.09 \mathrm{~mL}$, $0.71 \mathrm{mmol}$ ) and the solution was warmed to $-42{ }^{\circ} \mathrm{C}$. After $45 \mathrm{~min}$, the reaction mixture was cooled to $-78{ }^{\circ} \mathrm{C}$ and subsequently treated with a cold $\left(-78{ }^{\circ} \mathrm{C}\right)$ quenching solution $\left(1: 1: 1 \mathrm{MeOH} / \mathrm{Et}_{3} \mathrm{~N} \mathrm{CH}_{2} \mathrm{Cl}_{2}, 2.0 \mathrm{~mL}\right)$. Upon warming to room temperature, the solution was diluted with distilled $\mathrm{H}_{2} \mathrm{O}(4 \mathrm{~mL})$. The layers were separated, and the aqueous layer was extracted with $\mathrm{CH}_{2} \mathrm{Cl}_{2}(3 \times 4 \mathrm{~mL})$. The combined organic layers were washed with brine $(10 \mathrm{~mL})$, passed through a cotton plug, and concentrated in vacuo to afford a colorless oil. The resulting oil was purified by column chromatography (1:9 EtOAc/hexanes) to afford the product 26 (3:1 mixture of anomers) ${ }^{4}$ as a colorless oil (0.086 g, 86\%): ${ }^{1} \mathrm{H}$ NMR $\left(400 \mathrm{MHz}, \mathrm{CHCl}_{3}\right) \delta 4.65(\mathrm{~m}, 0.3 \mathrm{H}), 4.47$ (dd, $\left.J=6.3,3.9,1 \mathrm{H}\right), 3.91$ (ddd, $J=$ 11.8, 2.9, 1.0, 1H), 3.77 (m, containing: tt, $J=6.4,3.1,1.3 \mathrm{H}$ ), 3.65 (tt, $J=9.4,4.1,0.3 \mathrm{H}$ ), 3.52 (dd, $J=11.2,9.2,0.3 \mathrm{H}$ ), 3.43 (ddd, $J=$ 11.8, 5.6, 1.0, 1H), 2.26 (ddq, $J=13.1,8.4,4.0,1 \mathrm{H}), 2.08-1.86(\mathrm{~m}, 1.6 \mathrm{H}), 1.82-1.70(\mathrm{~m}, 1.3 \mathrm{H}), 1.68-1.59(\mathrm{~m}, 1.3 \mathrm{H}), 0.95(\mathrm{t}, J=$ 7.8, $11.7 \mathrm{H}), 0.59$ (q, $J=7.8,7.8 \mathrm{H}) ;{ }^{13} \mathrm{C}$ NMR $\left(125 \mathrm{MHz}, \mathrm{CDCl}_{3}\right) \delta 117.8,71.4,70.1,65.5,64.9,64.7,64.0,30.0,29.6,27.8,26.2,6.9$, 5.0, 4.9; IR (thin film) 2973, 2936, 2254, 1469, 1382, 1093, 1038, $918 \mathrm{~cm}^{-1}$; HRMS (GC-MS, EI) $\mathrm{m} / \mathrm{z}$ calcd for $\mathrm{C}_{12} \mathrm{H}_{23} \mathrm{NO}_{2} \mathrm{SiNa}$ $(\mathrm{M}+\mathrm{Na})^{+}$264.1396, found 264.1397.

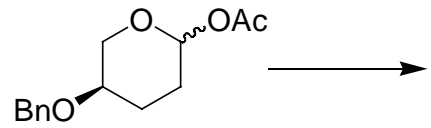

1<smiles>N#C[C@H]1CC[C@@H](OBr)CO1</smiles>

18

4-(Benzyloxy)-1-cyanotetrahydropyran (18). To a cooled $\left(-78^{\circ} \mathrm{C}\right)$ solution of the acetal $1(0.100 \mathrm{~g}, 0.45 \mathrm{mmol})$ in $\mathrm{CH}_{3} \mathrm{CN}(3.0$ $\mathrm{mL}$ ) was added $\mathrm{Me}_{3} \mathrm{SiCN}(0.20 \mathrm{~mL}, 1.5 \mathrm{mmol})$. After $2 \mathrm{~min}$, the solution was treated with $\mathrm{BF}_{3} \cdot \mathrm{OEt}_{2}(0.07 \mathrm{~mL}, 0.55 \mathrm{mmol})$ and warmed to $-45{ }^{\circ} \mathrm{C}$ and stirred for $1 \mathrm{~h}$. The reaction mixture was cooled to $-78{ }^{\circ} \mathrm{C}$ and subsequently treated with a cold $\left(-78{ }^{\circ} \mathrm{C}\right)$ quenching solution $\left(1: 1: 1 \mathrm{MeOH} / \mathrm{Et}_{3} \mathrm{~N} / \mathrm{CH}_{2} \mathrm{Cl}_{2}, 3.0 \mathrm{~mL}\right)$. Upon warming to room temperature, the solution was diluted with distilled $\mathrm{H}_{2} \mathrm{O}(4 \mathrm{~mL})$. The layers were separated, and the aqueous layer was extracted with $\mathrm{CH}_{2} \mathrm{Cl}_{2}(3 \times 4 \mathrm{~mL})$. The combined organic layers were washed with brine $(10 \mathrm{~mL})$, passed through a cotton plug, and concentrated in vacuo to afford a colorless oil (9:1 mixture of anomers). ${ }^{5}$ The resulting oil was purified by column chromatography (1:9 EtOAc/hexanes) to afford the product 18 as a colorless oil (0.085 g, 87\%): GC $t_{\mathrm{R}}$ major $10.96 \mathrm{~min}, t_{\mathrm{R}}$ minor $11.06 \mathrm{~min}\left(\mathrm{DB}-1,80{ }^{\circ} \mathrm{C}\right.$ for $1 \mathrm{~min}, 10^{\circ} \mathrm{C} / \mathrm{min}$ ramp for $17 \mathrm{~min}$ to $\left.250{ }^{\circ} \mathrm{C}, 25 \mathrm{psi}\right) ;{ }^{1} \mathrm{H}$ NMR (400 MHz, $\left.\mathrm{CHCl}_{3}\right) \delta 7.38-7.27(\mathrm{~m}, 5 \mathrm{H}), 4.47(\mathrm{t}, J=4.4,1 \mathrm{H}), 4.56$ (s, 2H), 3.94 (dd, $\left.J=12.4,2.3,1 \mathrm{H}\right), 3.78$ (ddd, $J=12.4$, 4.0, 1.6, 1H), 3.52 (ddt, $J=3.9,3.5,2.2,1 \mathrm{H}$ ), 2.32 (ddt, $J=14.0,10.7,4.3,1 \mathrm{H}$ ), 2.04 (ddt, $J=14.1,10.9,3.7,1 \mathrm{H}$ ), $1.95-1.85$ (m, 1H), 1.73 (dq, $J=13.9,4.3,1 \mathrm{H}) ;{ }^{13} \mathrm{C}$ NMR $\left(125 \mathrm{MHz}, \mathrm{CDCl}_{3}\right) \delta 138.1,128.6,127.9,127.7,117.5,70.6,70.2,67.4,64.7,25.1,24.8$; IR (thin film) 2254, 1469, 1382, $1096 \mathrm{~cm}^{-1}$; HRMS (GC-MS, EI) $\mathrm{m} / \mathrm{z}$ calcd for $\mathrm{C}_{13} \mathrm{H}_{15} \mathrm{NO}_{2} \mathrm{Na}(\mathrm{M}+\mathrm{Na})^{+}$240.1001, found 240.1008. 


\section{Synthesis of Five-Membered Ring Compounds}

The synthesis of acetals 3 and 7, hemiacetal 12, nitrile 13, and the allylated products 15 and 17 have previously been reported.,

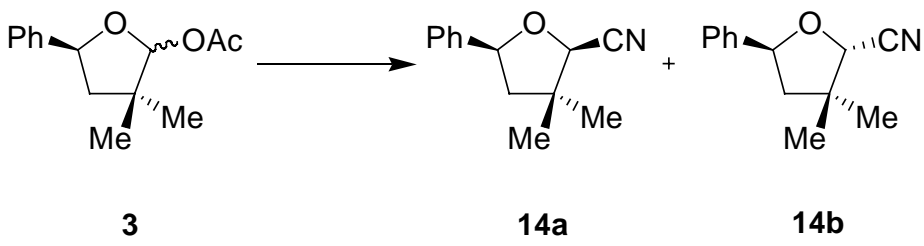

1-Cyano-2,2-dimethyl-4-phenyltetrahydrofuran (14a/14b). To a solution of acetate $3(0.050 \mathrm{~g}, 0.20 \mathrm{mmol})$ in $2 \mathrm{~mL}^{-} \mathrm{CH}_{2} \mathrm{Cl}_{2}$ was added trimethylsilyl cyanide $(0.050 \mathrm{~mL}, 0.40 \mathrm{mmol})$. The reaction mixture was cooled to $-78{ }^{\circ} \mathrm{C}$ and $\mathrm{BF}_{3} \cdot \mathrm{OEt}_{2}(0.050 \mathrm{~mL}, 0.40$ mmol) was added. After $2 \mathrm{~min}, 2 \mathrm{~mL}$ of a cooled $\left(-78{ }^{\circ} \mathrm{C}\right)$ 1:1:1 mixture of $\mathrm{Et}_{3} \mathrm{~N}, \mathrm{MeOH}$, and $\mathrm{CH}_{2} \mathrm{Cl}_{2}$ was added to the reaction mixture. The reaction mixture was warmed to $22{ }^{\circ} \mathrm{C}$. The reaction mixture was treated with saturated aqueous $\mathrm{NaHCO}_{3}(5 \mathrm{~mL})$ and the aqueous layer was then extracted with $\mathrm{Et}_{2} \mathrm{O}(3 \times 5 \mathrm{~mL})$. The organic layer was washed with brine $(5 \mathrm{~mL})$, dried $\left(\mathrm{Na}_{2} \mathrm{SO}_{4}\right)$, and concentrated in vacuo. GC analysis showed one peak while ${ }^{1} \mathrm{H}$ NMR spectroscopic analysis of the unpurified product showed a pair of diastereomers in a ratio of 50:50. Purification by flash chromatography (0:100 - 2:98 EtOAc/hexanes) yielded 14a (0.017 g, $43 \%)$ and $14 \mathrm{~b}(0.018 \mathrm{~g}, 45 \%)$ as colorless oils. HRMS and IR data were obtained for 14 as a mixture of diastereomers: IR (thin film) 2968, 2933, 2238, 1736, 1604, 1495, 1374, 1057, $757 \mathrm{~cm}^{-1}$; HRMS (GC-MS, EI) $\mathrm{m} / \mathrm{z}$ calcd for $\mathrm{C}_{13} \mathrm{H}_{15} \mathrm{NO}\left(\mathrm{M}^{+}\right)$201.1154, found 201.1149. (1R*,4S*)-1-Cyano-2,2-dimethyl-4-phenyltetrahydrofuran (14a). ${ }^{1} \mathrm{H}$ NMR (500 MHz, $\left.\mathrm{CDCl}_{3}\right) \delta 7.42-7.29$ (m, $\left.5 \mathrm{H}\right), 5.21$ (dd, $J=$ 10.3, 6.3, 1H), $4.46(\mathrm{~s}, 1 \mathrm{H}), 2.23$ (dd, $J=12.9,6.3,1 \mathrm{H}), 1.99$ (dd, $J=10.3,2.6,1 \mathrm{H}), 1.38(\mathrm{~s}, 3 \mathrm{H}), 1.33(\mathrm{~s}, 3 \mathrm{H}) ;{ }^{13} \mathrm{C} \mathrm{NMR}(125 \mathrm{MHz}$, $\left.\mathrm{CDCl}_{3}\right) \delta 141.3,128.8,128.1,126.0,118.3,82.8,77.7,48.5,44.5,26.0,24.2$.

(1S*,4S*)-1-Cyano-2,2-dimethyl-4-phenyltetrahydrofuran (14b). ${ }^{1} \mathrm{H}$ NMR (500 MHz, $\left.\mathrm{CDCl}_{3}\right) \delta$ 7.38-7.29 (m, $\left.5 \mathrm{H}\right), 5.28$ (dd, $J=$ 9.2, 7.0, $1 \mathrm{H}$ ), $4.53(\mathrm{~s}, 1 \mathrm{H}), 2.34$ (dd, $J=12.7,7.0,1 \mathrm{H}), 1.85$ (dd, $J=12.7,9.2,1 \mathrm{H}), 1.42(\mathrm{~s}, 3 \mathrm{H}), 1.27$ (s, 3H); ${ }^{13} \mathrm{C} \mathrm{NMR}(125 \mathrm{MHz}$, $\left.\mathrm{CDCl}_{3}\right) \delta 141.4,128.8,128.0,125.7,117.3,81.4,77.5,48.5,44.2,26.4,24.3$.

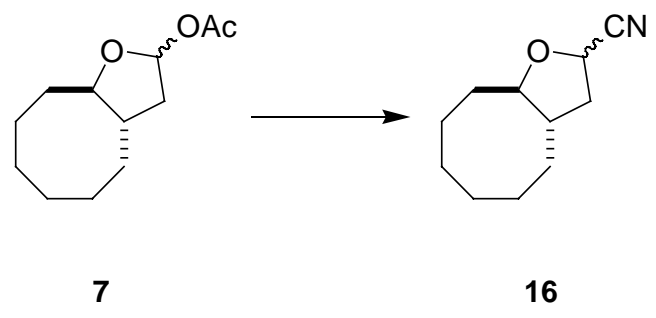

[6.3.0]-Bicyclic nitrile (16). To a solution of acetate $7(0.14 \mathrm{~g}, 0.64 \mathrm{mmol})$ in $6 \mathrm{~mL}$ of $\mathrm{CH}_{2} \mathrm{Cl}_{2}$ was added trimethylsilyl cyanide $(0.26 \mathrm{~mL}, 1.9 \mathrm{mmol})$. The reaction mixture was cooled to $-78{ }^{\circ} \mathrm{C}$ and $\mathrm{BF}_{3} \cdot \mathrm{OEt}_{2}(0.16 \mathrm{~mL}, 1.3 \mathrm{mmol})$ was added. After $30 \mathrm{~min}, 2 \mathrm{~mL}$ of a cooled $\left(-78{ }^{\circ} \mathrm{C}\right)$ 1:1:1 solution of $\mathrm{Et}_{3} \mathrm{~N}, \mathrm{MeOH}$, and $\mathrm{CH}_{2} \mathrm{Cl}_{2}$ was added to the reaction mixture. The reaction mixture was warmed to $22{ }^{\circ} \mathrm{C}$. The reaction mixture was treated with saturated aqueous $\mathrm{NaHCO}_{3}(5 \mathrm{~mL})$ and the aqueous layer was then extracted with $\mathrm{Et}_{2} \mathrm{O}(3 \times 5 \mathrm{~mL})$. The organic layer was washed with brine $(5 \mathrm{~mL})$, dried $\left(\mathrm{Na}_{2} \mathrm{SO}_{4}\right)$, and concentrated in vacuo. GC and ${ }^{1} \mathrm{H} \mathrm{NMR}$ spectroscopic analysis of the unpurified product showed a pair of diastereomers in a ratio of 54:46. Purification by flash chromatography (0:100 - 10:90 $\mathrm{Et}_{2} \mathrm{O} /$ pentane) yielded 16 as a colorless oil $(82 \%):{ }^{1} \mathrm{H}$ NMR $\left(500 \mathrm{MHz}, \mathrm{CDCl}_{3}\right) \delta 4.61$ (dd, $J=8.0$, 5.5, $1 \mathrm{H}$ ), 4.59 (dd, $J=8.0,1.6,0.5 \mathrm{H}$ ), 3.96 (td, $J=8.8,4.3,1 \mathrm{H}$ ), 3.90 (ddd, $J=10.0,8.4,4.6,0.5 \mathrm{H}$ ), 2.57 (ddd, $J=12.8,9.1,7.9,1 \mathrm{H}$ ), $2.40(\mathrm{~m}, 1 \mathrm{H}), 2.06(\mathrm{~m}, 2.5 \mathrm{H}), 1.93(\mathrm{~m}, 2.5 \mathrm{H}), 1.72(7 \mathrm{H}), 1.46(\mathrm{~m}, 9 \mathrm{H}) ;{ }^{13} \mathrm{C}$ NMR $\left(125 \mathrm{MHz}, \mathrm{CDCl}_{3}\right) \delta$ 120.3, 120.0, 86.8, 86.0, 64.7, 64.3, 43.0, 42.9, 41.8, 41.2, 35.8, 34.1, 33.8, 33.5, 27.9, 27.7, 27.0, 26.9, 25.3, 23.3, 23.0; IR (thin film) 2923, 2851, 2239, 1450, 1066, $1030 \mathrm{~cm}^{-1}$. Anal. Calcd for $\mathrm{C}_{11} \mathrm{H}_{17} \mathrm{NO}$ : C, 73.70; H, 9.56; N, 7.81. Found: C, 73.46; H, 9.70; N, 7.77.

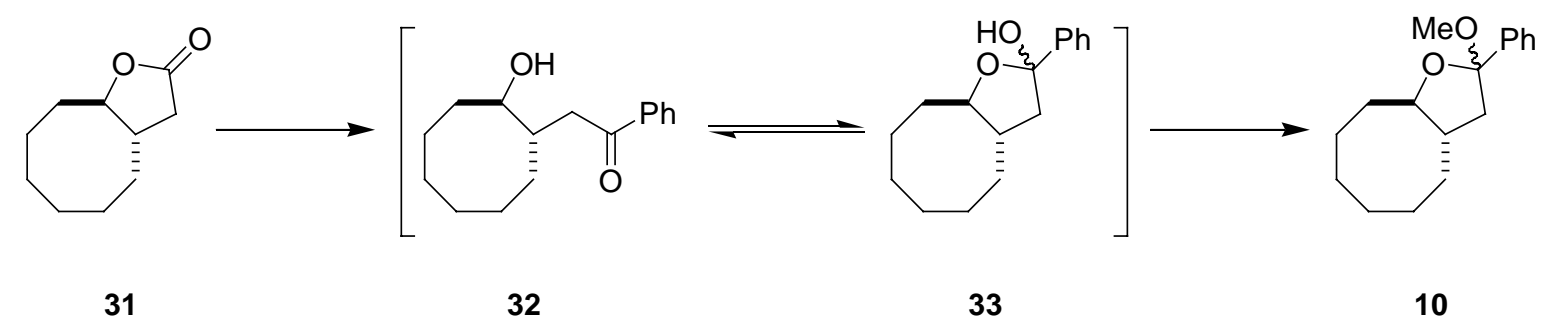

[6.3.0]-Bicyclic 1-phenyl-1-methyl acetal (10): Cerium chloride $\left(\mathrm{CeCl}_{3} \cdot 7 \mathrm{H}_{2} \mathrm{O}, 0.997 \mathrm{~g}, 4.05 \mathrm{mmol}\right)$, ground to a fine powder, was heated to $140{ }^{\circ} \mathrm{C}$ with evacuation $(133 \mathrm{~Pa})$. After $12 \mathrm{~h}$ at $140{ }^{\circ} \mathrm{C}$, the cerium chloride was cooled to $22^{\circ} \mathrm{C}$ and placed under an atmosphere of nitrogen. A solution of lactone $31^{8}(0.486 \mathrm{~g}, 2.89 \mathrm{mmol})$ in $30 \mathrm{~mL}$ of THF was added and the mixture was stirred for 1 
$\mathrm{h}$ at $22{ }^{\circ} \mathrm{C}$. The reaction mixture was cooled to $-45^{\circ} \mathrm{C}$ and methylmagnesium bromide (3.8 mL, $3.8 \mathrm{mmol}, 1.0 \mathrm{M}$ in THF) was added. After $1 \mathrm{~h}$ at $-45{ }^{\circ} \mathrm{C}$, the reaction mixture was treated with $15 \mathrm{~mL}$ of $\mathrm{H}_{2} \mathrm{O}$ and warmed to $22{ }^{\circ} \mathrm{C}$. The reaction mixture was filtered through a pad of Celite and extracted with $3 \times 20 \mathrm{~mL}$ of Et ${ }_{2} \mathrm{O}$. The combined organic phases were dried $\left(\mathrm{Na}_{2} \mathrm{SO}_{4}\right)$ and concentrated in vacuo. Due to the instability of the keto-lactol mixture, this mixture was converted to methyl acetal $\mathbf{1 0}$. A solution of ketone $\mathbf{3 2}$ and lactol 33 in $3.00 \mathrm{~mL}$ of a $0.1 \%$ solution of $\mathrm{HCl}$ in methanol was stirred for $25 \mathrm{~min}$. The reaction mixture was treated with $\mathrm{Ag}_{2} \mathrm{CO}_{3}$, filtered through a pad of Celite, and concentrated in vacuo. ${ }^{1} \mathrm{H}$ NMR spectroscopic analysis of the unpurified product showed a pair of diastereomers in a ratio of 58:42. Purification by flash chromatography (2:1:97 - 10:1:89 $\left.\mathrm{EtOAc}_{\mathrm{Et}} \mathrm{N} / \mathrm{hexanes}\right)$ provided 10 as a colorless oil $\left(0.320 \mathrm{~g}, 43 \%\right.$ over two steps). The purified product was characterized as a mixture of diastereomers: ${ }^{1} \mathrm{H}$ NMR (400 $\left.\mathrm{MHz}, \mathrm{CDCl}_{3}\right) \delta 7.46(\mathrm{~m}, 2.8 \mathrm{H}), 7.33(\mathrm{~m}, 2.8 \mathrm{H}), 7.26(\mathrm{~m}, 1.4 \mathrm{H}), 4.22$ (ddd, $\left.J=10.4,8.0,4.5,1 \mathrm{H}\right), 4.08$ (ddd, $\left.J=9.8,8.1,4.2,0.4 \mathrm{H}\right)$, 3.04 (s, 3H), $3.02(\mathrm{~s}, 1.2 \mathrm{H}), 2.57(\mathrm{~m}, 1 \mathrm{H}), 2.48(\mathrm{dd}, J=11.9,6.8,1 \mathrm{H}), 2.27(\mathrm{dd}, J=12.6,10.2,0.4 \mathrm{H}), 2.17(\mathrm{~m}, 2 \mathrm{H}), 2.01(\mathrm{dd}, J=$ 12.6, 5.9, 0.4H), $1.88(\mathrm{~m}, 3.6 \mathrm{H}), 1.71(\mathrm{~m}, 4.8 \mathrm{H}), 1.63(\mathrm{~m}, 1 \mathrm{H}), 1.58-1.36(\mathrm{~m}, 4.6 \mathrm{H}), 1.24(\mathrm{~m}, 2.2 \mathrm{H}) ;{ }^{13} \mathrm{C} \mathrm{NMR}\left(100 \mathrm{MHz}, \mathrm{CDCl}_{3}\right) \delta$ 141.5, 128.31, 128.25, 127.8, 127.7, 126.4, 126.3, 107.6, 86.9, 83.9, 51.6, 50.4, 49.5, 43.1, 43.0, 37.6, 35.0, 34.6, 34.5, 28.0, 27.7, 27.3, 27.2; ${ }^{1} \mathrm{H}$ NMR (500 MHz, $\left.\mathrm{C}_{6} \mathrm{D}_{6}\right) \delta 7.69(\mathrm{~m}, 3.2 \mathrm{H}), 7.25(\mathrm{~m}, 3.2 \mathrm{H}), 7.15(\mathrm{~m}, 1.6 \mathrm{H}), 4.18(\mathrm{~m}, 1.6 \mathrm{H}), 3.13(\mathrm{~s}, 1.8 \mathrm{H}), 3.10(\mathrm{~s}, 3 \mathrm{H})$, $2.53(\mathrm{~m}, 1.2 \mathrm{H}), 2.24(\mathrm{~m}, 2.6 \mathrm{H}), 2.12(\mathrm{dd}, J=12.9,5.8,1 \mathrm{H}), 1.90(\mathrm{~m}, 1 \mathrm{H}), 1.70(\mathrm{~m}, 3.2 \mathrm{H}), 1.55(\mathrm{~m}, 7 \mathrm{H}), 1.40(\mathrm{~m}, 1.6 \mathrm{H}), 1.32-1.01$ (m, 5.8H), 0.95 (m, 0.6H); ${ }^{13} \mathrm{C}$ NMR (125 MHz, $\left.\mathrm{C}_{6} \mathrm{D}_{6}\right) \delta 142.5,142.4,128.5,128.41,128.38,127.7,126.9,126.8,107.72,107.69$, 86.7, 83.8, 51.8, 50.7, 49.3, 49.2, 43.22, 43.16, 37.9, 35.2, 35.0, 34.5, 28.1, 27.8, 27.4, 27.3, 25.7, 25.5, 23.5; IR (thin film) 2927, 1446, 1325, $1021 \mathrm{~cm}^{-1}$. Anal. Calcd for $\mathrm{C}_{17} \mathrm{H}_{24} \mathrm{O}_{2}$ : C, 78.42; H, 9.29. Found: C, 78.23; H, 9.37.

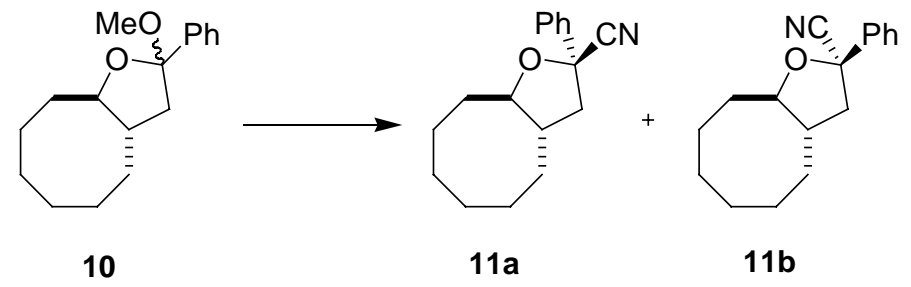

[6.3.0]-Bicyclic 1-phenyl-1-nitrile (11). To a solution of acetal $10(0.041 \mathrm{~g}, 0.16 \mathrm{mmol})$ in $2 \mathrm{~mL}$ of $\mathrm{CH}_{2} \mathrm{Cl}_{2}$ was added $\mathrm{Me}_{3} \mathrm{SiCN}$ $(0.090 \mathrm{~mL}, 0.64 \mathrm{mmol}) . \mathrm{BF}_{3} \cdot \mathrm{OEt}_{2}(0.040 \mathrm{~mL}, 0.32 \mathrm{mmol})$ was added to the cooled $\left(-78{ }^{\circ} \mathrm{C}\right)$ reaction mixture. After $2 \mathrm{~h}$ at $-78^{\circ} \mathrm{C}$, the reaction mixture was treated with $2 \mathrm{~mL}$ of a cooled $\left(-78^{\circ} \mathrm{C}\right)$ 1:1:1 mixture of $\mathrm{Et}_{3} \mathrm{~N}, \mathrm{MeOH}$, and $\mathrm{CH}_{2} \mathrm{Cl}_{2}$. The reaction mixture was warmed to $22^{\circ} \mathrm{C}$. The reaction mixture was treated with saturated aqueous $\mathrm{NaHCO}_{3}(5 \mathrm{~mL})$ and the aqueous layer was then extracted with $\mathrm{Et}_{2} \mathrm{O}(3 \times 5 \mathrm{~mL})$. The organic phases were washed with brine $(5 \mathrm{~mL})$, dried $\left(\mathrm{Na}_{2} \mathrm{SO}_{4}\right)$, and concentrated in vacuo. GC analysis of the unpurified product showed one peak. ${ }^{1} \mathrm{H}$ NMR spectroscopic analysis in $\mathrm{C}_{6} \mathrm{D}_{6}$ resolved key peaks to show a pair of diastereomers in a 96:4 ratio. Purification of the residue by flash chromatography (2:98 EtOAc/hexanes) yielded $\mathbf{1 1}(0.040 \mathrm{~g}, 95 \%)$. The purified product was characterized as a mixture of diastereomers: IR (thin film) 2927, 2232, 1462, 1446, $1067 \mathrm{~cm}^{-1}$; HRMS (EI) $\mathrm{m} / \mathrm{z}$ calcd for $\mathrm{C}_{17} \mathrm{H}_{21} \mathrm{NONa}(\mathrm{M}+\mathrm{Na})^{+}$278.1521, found 278.1523. Anal. Calcd for $\mathrm{C}_{17} \mathrm{H}_{21} \mathrm{NO}$ : C, 79.96; H, 8.29; N, 5.49. Found: C, 80.02; H, 8.39; N, 5.42 .

1,3-trans diastereomer 11a. ${ }^{1} \mathrm{H}$ NMR $\left(500 \mathrm{MHz}, \mathrm{CDCl}_{3}\right) \delta 7.53(\mathrm{~m}, 2 \mathrm{H}), 7.41-7.34(\mathrm{~m}, 3 \mathrm{H}), 4.25(\mathrm{td}, J=9.3,4.8,1 \mathrm{H}), 2.84(\mathrm{dd}, J=$ 12.7, 6.3, $1 \mathrm{H}), 2.67(\mathrm{~m}, 1 \mathrm{H}), 2.20(\mathrm{~m}, 1 \mathrm{H}), 2.01-1.69(\mathrm{~m}, 7 \mathrm{H}), 1.51(\mathrm{~m}, 3 \mathrm{H}), 1.30(\mathrm{~m}, 2 \mathrm{H}) ;{ }^{13} \mathrm{C}$ NMR $\left(125 \mathrm{MHz}, \mathrm{CDCl}_{3}\right) \delta 138.9$, 129.0, 128.9, 125.0, 121.8, 87.6, 78.7, 52.0, 44.5, 36.0, 33.4, 27.7, 27.0, 25.3, 22.9; ${ }^{1} \mathrm{H}$ NMR $\left(500 \mathrm{MHz}, \mathrm{C}_{6} \mathrm{D}_{6}\right) \delta 7.52(\mathrm{~m}, 2 \mathrm{H}), 7.09$ (m, 2H), $7.04(\mathrm{~m}, 1 \mathrm{H}), 3.90$ (ddd, $J=10.1,8.1,4.7,1 \mathrm{H}), 2.35(\mathrm{~m}, 2 \mathrm{H}), 2.10$ (dddd, $J=13.9,9.2,4.8,2.7,1 \mathrm{H}), 1.91(\mathrm{~m}, 1 \mathrm{H}), 1.57-$ 1.33 (m, 6H), 1.20 (m, 2H), 1.07 (m, 1H), $0.96(\mathrm{~m}, 1 \mathrm{H}), 0.76$ (m, 1H); ${ }^{13} \mathrm{C}$ NMR (125 MHz, $\left.\mathrm{C}_{6} \mathrm{D}_{6}\right) \delta$ 139.9, 129.0, 128.9, 125.3, 122.0, 87.4, 78.7, 51.9, 44.4, 36.2, 33.2, 27.7, 27.1, 25.3, 22.9.

1,3-cis diastereomer 11b. ${ }^{1} \mathrm{H}$ NMR (500 MHz, $\mathrm{CDCl}_{3}$, distinctive peaks) $\delta 2.53$ (dd, $\left.J=13.0,9.7,1 \mathrm{H}\right), 2.45$ (dd, $J=13.4,6.8,1 \mathrm{H}$ ); ${ }^{1} \mathrm{H}$ NMR (500 MHz, $\mathrm{C}_{6} \mathrm{D}_{6}$, distinctive peak) $\delta 2.53$ (dd, $J=13.0,9.7,1 \mathrm{H}$ ). 


\section{Synthesis of Solid-Supported Compounds}

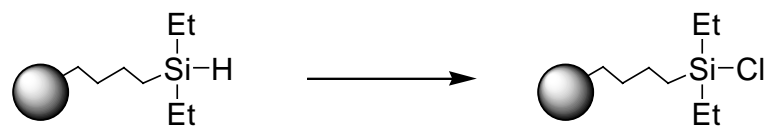

Polystyrene Chlorodiethylsilane (36). ${ }^{9}$ A $10-\mathrm{mL}$ round-bottom flask equipped with a magnetic stir bar and nitrogen inlet was charged with polystyrene diethylsilane resin 35 (1.56 mmol/g) and 1,3-dichloro-5,5-dimethylhydantoin (3 equiv). The solids were suspended in $\mathrm{CH}_{2} \mathrm{Cl}_{2}$ (3.2 mL/mmol 1,3-dichloro-5,5-dimethylhydantoin), and stirred at $25{ }^{\circ} \mathrm{C}$. After $1.5 \mathrm{~h}$, the solvent was removed by high gauge cannula (1.5mm outer diameter $\times 0.25 \mathrm{~mm}$ inner diameter). The resin was washed with $\mathrm{CH}_{2} \mathrm{Cl}_{2}(3 \times 3 \mathrm{~mL})$ and THF $(3$ $\times 3 \mathrm{~mL}$ ). The resin was used for further transformations immediately after washing.

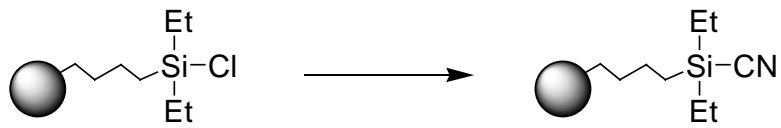

36

24

Polystyrene Diethylsilyl Cyanide (24). ${ }^{10}$ A 25 -mL two-neck round-bottom flask equipped with a magnetic stir bar and a reflux condenser with a nitrogen inlet was charged with the polystyrene chlorodiethylsilane $36^{9}$ prepared by the above procedure $(0.10 \mathrm{~g}$, $0.15 \mathrm{mmol})$ and $\mathrm{Me}_{3} \mathrm{SiCN}(1.50 \mathrm{~mL}, 11.0 \mathrm{mmol})$. The suspension was heated to $80{ }^{\circ} \mathrm{C}$ and stirred gently. After $36 \mathrm{~h}$, the suspension was cooled to $25^{\circ} \mathrm{C}$, and the excess $\mathrm{Me}_{3} \mathrm{SiCN}$ was removed by high gauge cannula ( $1.5 \mathrm{~mm}$ outer diameter $\times 0.25 \mathrm{~mm}$ inner diameter). The silyl cyanide resin 24 was washed with $\mathrm{CH}_{2} \mathrm{Cl}_{2}(20 \times 1 \mathrm{~mL})$ and dried in vacuo at $40{ }^{\circ} \mathrm{C}$ for $18 \mathrm{~h}$. IR (KBr pellet) $2185 \mathrm{~cm}^{-1}$.

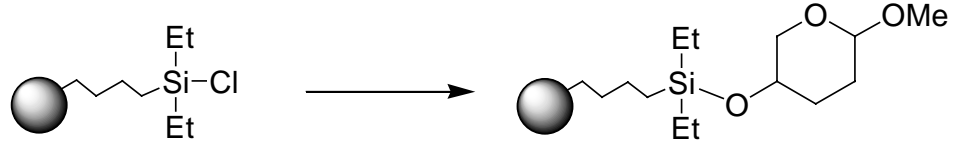

Polystyrene Diethylsilyloxytetrahydropyran Acetal (27). A 25-mL round-bottom flask equipped with a magnetic stir bar and a nitrogen inlet was charged with the polystyrene chlorodiethylsilane 36 prepared by the above procedure $(0.12 \mathrm{~g}, 0.17 \mathrm{mmol})$. The resin was treated with a solution of the alcohol $30(0.07 \mathrm{~g}, 0.53 \mathrm{mmol})$ and imidazole $(0.06 \mathrm{~g}, 0.9 \mathrm{mmol})$ in $\mathrm{CH}_{2} \mathrm{Cl}_{2}(2.0 \mathrm{~mL})$. The suspension was stirred at $25{ }^{\circ} \mathrm{C}$. After $18 \mathrm{~h}$, the resin was treated with $\mathrm{MeOH}(5 \mathrm{~mL})$ and filtered and washed sequentially with $\mathrm{CH}_{2} \mathrm{Cl}_{2}(3 \times 10 \mathrm{~mL})$, DMF $(3 \times 10 \mathrm{~mL}), \mathrm{CH}_{3} \mathrm{CN}(3 \times 10 \mathrm{~mL})$, THF $(3 \times 10 \mathrm{~mL})$, and $\mathrm{CH}_{2} \mathrm{Cl}_{2}(3 \times 10 \mathrm{~mL})$. The polystyrene-bound silyloxy acetal resin 27 was dried in vacuo for $18 \mathrm{~h} .{ }^{11}$

The loading of the tetrahydropyran acetal was determined by cleavage from the solid support and analysis by GC. A small portion of the polystyrene-bound silyloxy acetal resin $27(0.018$ g) was suspended in THF and treated with tetrabutylammoniumfluoride $(1.0 \mathrm{M}$ solution in THF, $0.1 \mathrm{~mL}, 0.10 \mathrm{mmol})$ and warmed to $60{ }^{\circ} \mathrm{C}$. After $12 \mathrm{~h}$, the reaction mixture was cooled to $25{ }^{\circ} \mathrm{C}$ and filtered. The resin was washed with EtOAc $(3 \times 10 \mathrm{~mL})$. The filtrate was washed with saturated aqueous $\mathrm{NaHCO}_{3}(10 \mathrm{~mL})$. The organic layer was concentrated in vacuo to afford a trace residue. The residue was treated with anthracene (0.04 M solution in EtOAc, $0.2 \mathrm{~mL}, 8.0 \mu \mathrm{mol}$ ). Analysis by GC indicated a 63\% loading of the acetal on the polystyrene solid support.

Experimental Setup for the Three-Phase Test. A two-neck round-bottom flask outfitted with a fritted glass membrane (figure 1) was used in the three-phase test and the subsequent control experiments described below.

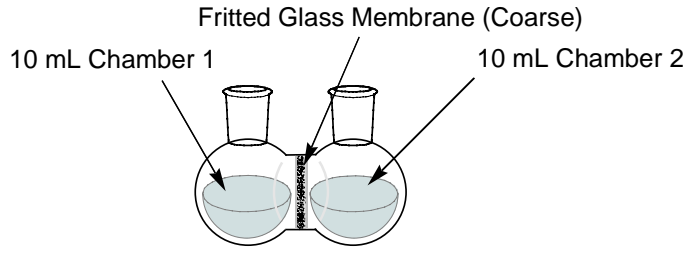


Three-Phase Test. The 10-mL chamber 1 of the two-neck round-bottom flask in figure 1, equipped with a magnetic stir bar, was charged with polystyrene diethylsilyl cyanide $24(0.10 \mathrm{~g}, 0.15 \mathrm{mmol})$ and the $10-\mathrm{mL}$ chamber 2, equipped with a magnetic stir bar, was charged with polystyrene diethylsilyloxytetrahydropyran acetal $27(0.16 \mathrm{~g}, 0.04 \mathrm{mmol})$. Both chambers were filled with $\mathrm{CH}_{2} \mathrm{Cl}_{2}$ ( $5.0 \mathrm{~mL}$ per chamber, $10 \mathrm{~mL}$ total) and the apparatus was cooled to $-78{ }^{\circ} \mathrm{C}$. After $2 \mathrm{~min}$, both chambers were treated with $\mathrm{BF}_{3} \cdot \mathrm{OEt}_{2}$ ( $0.05 \mathrm{~mL}$ per chamber, $0.10 \mathrm{~mL}$ total). The reaction mixtures were slowly warmed to $25^{\circ} \mathrm{C}$ and stirred gently. After 4 days, chamber 2 was treated with saturated aqueous $\mathrm{NaHCO}_{3}(5.0 \mathrm{~mL})$ and filtered. The resin was washed sequentially with $\mathrm{CH}_{2} \mathrm{Cl}_{2}(3 \times 5 \mathrm{~mL})$, DMF $(3 \times 5 \mathrm{~mL})$, THF $(3 \times 5 \mathrm{~mL})$, $\mathrm{MeOH}(3 \times 5 \mathrm{~mL})$, THF $(3 \times 5 \mathrm{~mL})$, and $\mathrm{CH}_{2} \mathrm{Cl}_{2}(3 \times 5 \mathrm{~mL})$. The resin was dried in vacuo for 18h. IR ( $\mathrm{KBr}$ pellet) did not show any signals corresponding to a $\mathrm{C} \equiv \mathrm{N}$ stretch. These data indicate that the reaction of a silyl cyanide with a cyclic oxocarbenium ion does not involve free cyanide ion.

Reaction of Polystyrene Diethylsilyl Cyanide 24 with Solution-Phase Acetal 25. The $10 \mathrm{~mL}$ chamber 1 of the two-neck round-bottom flask in figure 1, equipped with a magnetic stir bar, was charged with polystyrene diethylsilyl cyanide 24 (0.04 g, 0.07 $\mathrm{mmol}$ ), and the $10 \mathrm{~mL}$ chamber 2, equipped with a magnetic stir bar, was charged with the triethylsilyloxy acetal 25 (6.0 mg, 0.02 $\mathrm{mmol})$. Both chambers were filled with $\mathrm{CH}_{2} \mathrm{Cl}_{2}(1.0 \mathrm{~mL}$ per chamber, $2.0 \mathrm{~mL}$ total $)$ and cooled to $-78{ }^{\circ} \mathrm{C}$. After $2 \mathrm{~min}$ at $-78{ }^{\circ} \mathrm{C}$, both chambers were treated with $\mathrm{BF}_{3} \cdot \mathrm{OEt}_{2}\left(5.0 \mu \mathrm{L}\right.$ per chamber, $0.01 \mathrm{~mL}$ total). The reaction mixtures were slowly warmed to $25^{\circ} \mathrm{C}$ and stirred gently. After $2 \mathrm{~h}$, both chambers were treated with a cold $\left(-78{ }^{\circ} \mathrm{C}\right)$ quenching solution $\left(1: 1: 1 \mathrm{MeOH} / \mathrm{Et}_{3} \mathrm{~N} / \mathrm{CH}_{2} \mathrm{Cl}_{2}, 1.0 \mathrm{~mL}\right.$ per chamber, $2.0 \mathrm{~mL}$ total). After warming to $25^{\circ} \mathrm{C}$, the contents of both chambers were filtered. The resin was washed with $\mathrm{Et}_{2} \mathrm{O}(3 \times 5$ $\mathrm{mL})$. The filtrate was washed with saturated aqueous $\mathrm{NaHCO}_{3}(10 \mathrm{~mL})$. The organic layer was concentrated in vacuo to afford a trace residue. IR (thin film) $2254 \mathrm{~cm}^{-1}$; LRMS (ESI) $\mathrm{m} / \mathrm{z}$ calcd for $\mathrm{C}_{12} \mathrm{H}_{24} \mathrm{NO}_{2} \mathrm{Si}(\mathrm{M}+\mathrm{H})^{+}$242.4, found 242.4. This IR stretch corresponds to the $\mathrm{C} \equiv \mathrm{N}$ stretch of the anomeric nitrile.

Reaction of Polystyrene Diethylsilyloxytetrahydropyran Acetal 27 with Solution-Phase $\mathbf{M e}_{3}$ SiCN. The $10 \mathrm{~mL}$ chamber 1 of the two-neck round-bottom flask in figure 1, equipped with a magnetic stir bar, was charged with polystyrene diethylsilyloxytetrahydropyran acetal $27(0.04 \mathrm{~g}, 0.03 \mathrm{mmol})$, and the $10-\mathrm{mL}$ chamber 2, equipped with a magnetic stir bar, was charged with $\mathrm{Me}_{3} \mathrm{SiCN}(0.02 \mathrm{~mL}, 0.15 \mathrm{mmol})$ Both chambers were filled with $\mathrm{CH}_{2} \mathrm{Cl}_{2}(1.0 \mathrm{~mL}$ per chamber, $2.0 \mathrm{~mL}$ total) and cooled to $-78{ }^{\circ} \mathrm{C}$. After $2 \mathrm{~min}$, both chambers were treated with $\mathrm{BF}_{3} \cdot \mathrm{OEt}_{2}(5.0 \mu \mathrm{L}$ per chamber, $0.01 \mathrm{~mL}$ total). The reaction mixture was slowly warmed to $25{ }^{\circ} \mathrm{C}$ and stirred gently. After $2 \mathrm{~h}$, both chambers were treated with a cold $\left(-78{ }^{\circ} \mathrm{C}\right)$ quenching solution $(1: 1: 1$ $\mathrm{MeOH} / \mathrm{Et}_{3} \mathrm{~N} / \mathrm{CH}_{2} \mathrm{Cl}_{2}, 1.0 \mathrm{~mL}$ per chamber, $2.0 \mathrm{~mL}$ total). After warming to $25^{\circ} \mathrm{C}$, the contents of both chambers were filtered. The resin was washed with $\mathrm{Et}_{2} \mathrm{O}(10 \times 5 \mathrm{~mL})$ and dried in vacuo for $18 \mathrm{~h}$. IR (KBr pellet) $2258 \mathrm{~cm}^{-1}$. This IR stretch corresponds to the $\mathrm{C} \equiv \mathrm{N}$ stretch of the anomeric nitrile.

The tetrahydropyran acetal was cleaved from the solid support and analyzed by GC. Resin 28 (0.030 g, 0.03 mmol) was suspended in THF and treated with tetrabutylammoniumfluoride (1.0 M solution in THF, $0.1 \mathrm{~mL}, 0.10 \mathrm{mmol})$ and warmed to $60{ }^{\circ} \mathrm{C}$. After $18 \mathrm{~h}$, the reaction mixture was cooled to $25^{\circ} \mathrm{C}$ and filtered. The resin was washed with $\mathrm{Et}_{2} \mathrm{O}(3 \times 10 \mathrm{~mL})$. The filtrate was washed with saturated aqueous $\mathrm{NaHCO}_{3}(10 \mathrm{~mL})$. The organic layer was concentrated in vacuo to afford a trace residue. IR (thin film) $2251 \mathrm{~cm}^{-1}$; LRMS (ESI) $\mathrm{m} / \mathrm{z}$ calcd for $\mathrm{C}_{6} \mathrm{H}_{9} \mathrm{NO}_{2} \mathrm{Na}(\mathrm{M}+\mathrm{Na})^{+} 150.1$, found 150.1. This IR stretch corresponds to the $\mathrm{C} \equiv \mathrm{N}$ stretch of the anomeric nitrile. This LRMS corresponds to the anomeric nitrile product.

\section{General Procedures for Competition Experiments}

Procedure A: Competition Experiments without $\mathrm{Bu}_{4} \mathbf{N C N}$ Additive: To a cooled $\left(-78{ }^{\circ} \mathrm{C}\right)$ solution of acetate $(0.15-0.20$ $\mathrm{mmol}$ ) in dry solvent $(0.15 \mathrm{M})$ was added trimethylsilyl cyanide (4.0 equiv) and allyltrimethylsilane (4.0 equiv) simultaneously by syringe. To the cooled $\left(-78{ }^{\circ} \mathrm{C}\right.$ ) reaction mixture was added $\mathrm{BF}_{3} \cdot \mathrm{OEt}_{2}$ (1.3 equiv) dropwise by syringe. After $30 \mathrm{~min}$ at $-78{ }^{\circ} \mathrm{C}, 2 \mathrm{~mL}$ of a cold $\left(-78{ }^{\circ} \mathrm{C}\right)$ quenching solution $\left(1: 1: 1 \mathrm{MeOH} / \mathrm{Et}_{3} \mathrm{~N} / \mathrm{CH}_{2} \mathrm{Cl}_{2}\right)$ was added. The reaction mixture was warmed to $22{ }^{\circ} \mathrm{C}$. The reaction mixture was treated with aqueous $\mathrm{NaHCO}_{3}(5 \mathrm{~mL})$ and the aqueous layer was extracted with $\mathrm{Et}_{2} \mathrm{O}(3 \times 2 \mathrm{~mL})$. The combined organic layers were washed with brine $(5 \mathrm{~mL})$, dried over $\mathrm{Na}_{2} \mathrm{SO}_{4}$, and concentrated in vacuo. The product ratio was determined by ${ }^{1} \mathrm{H}$ NMR analysis of the unpurified reaction mixture. Diastereomeric ratios were determined by GC analysis of the unpurified mixture and corroborated by ${ }^{1} \mathrm{H}$ NMR analysis.

Procedure B: Competition Experiments with $\mathrm{Bu}_{4} \mathrm{NCN}$ Additive: To a cooled $\left(-78{ }^{\circ} \mathrm{C}\right)$ solution of acetate $(0.15-0.20 \mathrm{mmol})$ in dry solvent $(0.15 \mathrm{M})$ was added a solution of $\mathrm{Bu}_{4} \mathrm{NCN}$ (4.0 equiv), trimethylsilyl cyanide (4.0 equiv) and allyltrimethylsilane (4.0 equiv) in $\mathrm{CH}_{2} \mathrm{Cl}_{2}(1 \mathrm{~mL})$ dropwise by syringe. To the cooled $\left(-78^{\circ} \mathrm{C}\right)$ reaction mixture was added $\mathrm{BF}_{3} \cdot \mathrm{OEt}_{2}(1.3$ equiv) dropwise by syringe. After $30 \mathrm{~min}$ at $-78{ }^{\circ} \mathrm{C}, 2 \mathrm{~mL}$ of a cold $\left(-78{ }^{\circ} \mathrm{C}\right)$ quenching solution $\left(1: 1: 1 \mathrm{MeOH} / \mathrm{Et}_{3} \mathrm{~N} / \mathrm{CH}_{2} \mathrm{Cl}_{2}\right)$ was added. The reaction mixture was warmed to $22^{\circ} \mathrm{C}$. The reaction mixture was treated with aqueous $\mathrm{NaHCO}_{3}(5 \mathrm{~mL})$ and the aqueous layer was extracted with $\mathrm{Et}_{2} \mathrm{O}(3 \times 2 \mathrm{~mL})$. The combined organic layers were washed with brine $(5 \mathrm{~mL})$, dried over $\mathrm{Na}_{2} \mathrm{SO}_{4}$, and concentrated in vacuo. The product ratio was determined by ${ }^{1} \mathrm{H}$ NMR analysis of the unpurified reaction mixture. Diastereomeric ratios were determined by GC analysis of the unpurified mixture and corroborated by ${ }^{1} \mathrm{H}$ NMR analysis. 


\section{Stereochemical Proofs}

\section{4-(benzyloxy)-1-cyanotetrahydropyran (18):}

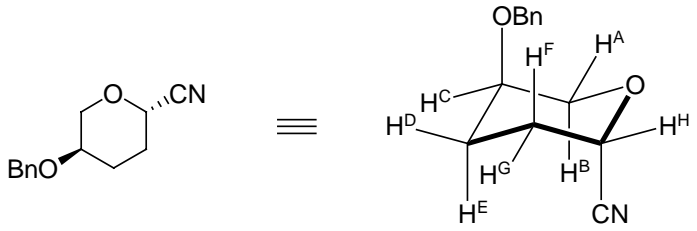

$\mathrm{H}^{\mathrm{A}}: \quad \delta 3.78$, ddd, $J=12.4\left(\mathrm{gem}^{\mathrm{e}} \mathrm{eq}^{\mathrm{A}}-\mathrm{ax}^{\mathrm{B}}\right), 4.0\left(\mathrm{eq}^{\mathrm{A}}-\mathrm{eq}^{\mathrm{C}}\right), 1.6\left(\mathrm{~W}\right.$-coupling to $\left.\mathrm{H}^{\mathrm{D}}\right)$

$\mathrm{H}^{\mathrm{B}}: \quad \delta 3.94$, dd, $J=12.4\left(\mathrm{gem}^{\mathrm{a}} \mathrm{ax}^{\mathrm{B}}-\mathrm{eq}^{\mathrm{A}}\right), 2.3\left(\mathrm{ax}^{\mathrm{B}}-\mathrm{eq}^{\mathrm{C}}\right)$

$\mathrm{H}^{\mathrm{C}}: \quad \delta 3.52$, ddt, $J=3.9\left(\mathrm{eq}^{\mathrm{C}}-\mathrm{eq}^{\mathrm{A}}\right), 3.5\left(\mathrm{eq}^{\mathrm{C}}-\mathrm{eq}^{\mathrm{D}}\right), 2.2\left(\mathrm{eq}^{\mathrm{C}}-\mathrm{ax}^{\mathrm{B}}, \mathrm{eq}^{\mathrm{C}}-\mathrm{ax}^{\mathrm{E}}\right)$

$\mathrm{H}^{\mathrm{D}}: \quad \delta 1.95-1.85, \mathrm{~m}$

$\mathrm{H}^{\mathrm{E}}: \quad \delta 2.04$, ddt, $J=14.2\left(\mathrm{gem}^{\mathrm{a}} \mathrm{ax}^{\mathrm{E}}-\mathrm{eq}^{\mathrm{D}}\right), 10.9\left(\mathrm{ax}^{\mathrm{E}}-\mathrm{ax}^{\mathrm{F}}\right), 3.7\left(\mathrm{ax}^{\mathrm{E}}-\mathrm{eq}^{\mathrm{C}}, \mathrm{ax}^{\mathrm{E}}-\mathrm{eq}^{\mathrm{G}}\right)$

$\mathrm{H}^{\mathrm{F}}: \quad \delta 2.32$, ddt, $J=14.0\left(\right.$ gem, $\left.\mathrm{ax}^{\mathrm{F}}-\mathrm{eq}^{\mathrm{G}}\right), 10.7\left(\mathrm{ax}^{\mathrm{F}}-\mathrm{ax}^{\mathrm{E}}\right), 4.3\left(\mathrm{ax}^{\mathrm{F}}-\mathrm{eq}^{\mathrm{D}}, \mathrm{ax}^{\mathrm{F}}-\mathrm{eq}^{\mathrm{H}}\right)$

$\mathrm{H}^{\mathrm{G}}: \quad \delta 1.73, \mathrm{dq}, J=13.9\left(\mathrm{gem}, \mathrm{eq}^{\mathrm{G}}-\mathrm{ax}^{\mathrm{F}}\right), 4.3\left(\mathrm{eq}^{\mathrm{G}}-\mathrm{eq}^{\mathrm{D}}, \mathrm{eq}^{\mathrm{G}}-\mathrm{ax}^{\mathrm{E}}, \mathrm{eq}^{\mathrm{G}}-\mathrm{eq}^{\mathrm{H}}\right)$

$\mathrm{H}^{\mathrm{H}}: \quad \delta 4.47, \mathrm{t}, J=4.4\left(\mathrm{eq}^{\mathrm{H}}-\mathrm{ax}^{\mathrm{F}}, \mathrm{eq}^{\mathrm{H}}-\mathrm{eq}^{\mathrm{G}}\right)$

\section{1-Cyano-2,2-dimethyl-4-phenyltetrahydrofuran (14a/14b):}

The stereochemistry of nitrile product $\mathbf{1 4}$ was determined by analysis of NOE data:

Relevant DPFGSE-nOe data (mixing time $2.0 \mathrm{~s}$ ): (the peaks in the ${ }^{1} \mathrm{H}$ NMR spectra were assigned using ${ }^{1} \mathrm{H} /{ }^{1} \mathrm{H} \mathrm{COSY},{ }^{1} \mathrm{H}$ NMR chemical shifts, and ${ }^{1} \mathrm{H}$ NMR coupling constants)

$\left(1 R^{*}, 4 S^{*}\right)-1-C y a n o-2,2-d i m e t h y l-4-p h e n y l t e t r a h y d r o f u r a n ~(1,4-c i s, 14 a):$

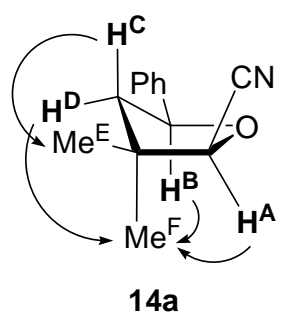

NOE experiments were performed for 14a using a pure sample of the 1,4-cis diastereomer.

$\mathbf{H}^{\mathrm{A}}$ irradiated: $\mathrm{Me}^{\mathrm{E}}(1.2 \%), \mathrm{Me}^{\mathrm{F}}(3.0 \%)$

$\mathbf{H}^{\mathbf{B}}$ irradiated: $\mathrm{H}^{\mathrm{A}}(0.8 \%), \mathrm{H}^{\mathrm{D}}(3.0 \%), \mathrm{Me}^{\mathrm{F}}(4.4 \%)$

$\mathbf{H}^{\mathrm{C}}$ irradiated: $\mathrm{Me}^{\mathrm{E}}(4.2 \%)$

$\mathbf{H}^{\mathbf{D}}$ irradiated: $\mathrm{H}^{\mathrm{B}}$ (4.9\%), $\mathrm{Me}^{\mathrm{F}}(2.5 \%)$

Note: The absence of an NOE between $\mathrm{H}^{\mathrm{A}}$ and $\mathrm{Ph}$ indicates 1,4-cis configuration. 
(1S*,4S*)-1-Cyano-2,2-dimethyl-4-phenyltetrahydrofuran (1,4-trans, 14b):

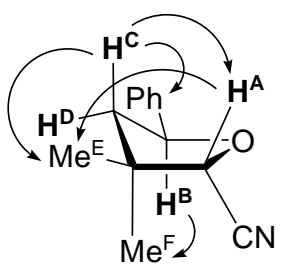

$14 b$

NOE experiments were performed for $\mathbf{1 4 b}$ using a pure sample of the 1,4-trans diastereomer.

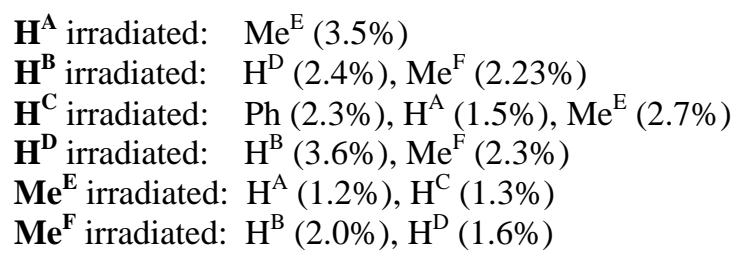

Note: The absence of an NOE between $\mathrm{H}^{\mathrm{A}}$ and $\mathrm{H}^{\mathrm{B}}$ indicates a 1,4-trans configuration.

\section{[6.3.0]-Bicyclic 1-phenyl-1-nitrile (11):}

The stereochemistry of nitrile $\mathbf{1 1}$ was determined by conversion to amine $\mathbf{3 4}$ and subsequent analysis of NOE data of $\mathbf{3 4}$ :

Relevant DPFGSE-NOE data (mixing time $2.0 \mathrm{~s}$ ): (the peaks in the ${ }^{1} \mathrm{H}$ NMR spectra were assigned using ${ }^{1} \mathrm{H} /{ }^{1} \mathrm{H} \mathrm{COSY},{ }^{1} \mathrm{H}$ NMR chemical shifts, and ${ }^{1} \mathrm{H}$ NMR coupling constants)

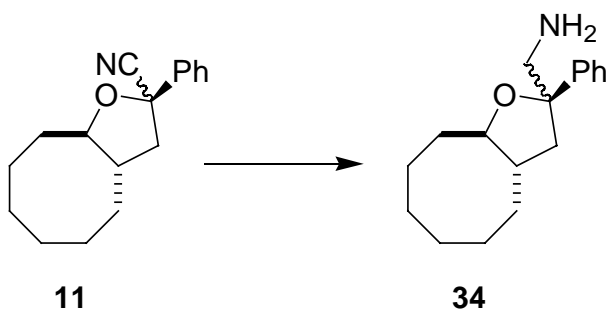

8,5-Bicyclic methylamine (34): To a cooled $\left(0^{\circ} \mathrm{C}\right)$ solution of $\mathrm{AlH}_{3}(2.04 \mathrm{~mL}, 1.02 \mathrm{mmol}, 0.50 \mathrm{M}$ in THF) was added nitrile $11(0.044 \mathrm{~g}, 0.17 \mathrm{mmol})$ in $3 \mathrm{~mL}$ of THF. ${ }^{12}$ After $36 \mathrm{~h}$ at $22{ }^{\circ} \mathrm{C}$, the reaction mixture was treated with $30.6 \mu \mathrm{L}$ of $\mathrm{H}_{2} \mathrm{O}$, $30.6 \mu \mathrm{L}$ of $15 \% \mathrm{NaOH}, 92 \mathrm{~mL}$ of $\mathrm{H}_{2} \mathrm{O}$, and $20 \mathrm{mg}$ of $\mathrm{Na}_{2} \mathrm{SO}_{4}$. The mixture was filtered through filter paper and concentrated in vacuo to provide the product as an oil. Purification of this residue by flash chromatography (1:5:94 - 1:30:69 $\left.\mathrm{Et}_{3} \mathrm{~N} / \mathrm{EtOAc} / \mathrm{hexanes}\right)$ afforded 34 (0.036 g, 80\%). Methylamine 34 was characterized as a mixture of diastereomers: ${ }^{1} \mathrm{H}$ NMR (500 MHz, $\left.\mathrm{CDCl}_{3}\right) \delta$ 7.42-7.31 (m, 5.2H), 7.20 (m, 1.3H), $3.83(\mathrm{td}, J=9.1,3.8,0.3 \mathrm{H}), 3.76(\mathrm{td}, J=9.1,4.1,1 \mathrm{H}), 2.86$ (s, 0.6H), 2.80 (dd, $J=18.2,13.3,2 \mathrm{H}), 2.46$ (dd, $J=12.5,8.5,1 \mathrm{H}), 2.32$ (m, 0.3H), 2.15 (m, $2 \mathrm{H}), 1.90$ (m, $0.6 \mathrm{H}), 1.85$ (dd, $J$ $=12.5,9.7,1 \mathrm{H}), 1.78(\mathrm{~m}, 2 \mathrm{H}), 1.63(\mathrm{~m}, 5 \mathrm{H}), 1.45-1.25(\mathrm{~m}, 9 \mathrm{H}), 1.52(\mathrm{~m}, 1.3 \mathrm{H}) ;{ }^{13} \mathrm{C}$ NMR $\left(125 \mathrm{MHz}, \mathrm{CDCl}{ }_{3}, \mathrm{major}\right.$ diastereomer) $\delta$ 146.8, 128.7, 127.0, 125.8, 85.0, 53.8, 46.9, 45.2, 35.4, 33.5, 28.6, 27.4, 26.3, 24.0 ; ${ }^{13} \mathrm{C} \mathrm{NMR} \mathrm{(125} \mathrm{MHz}$, $\mathrm{CDCl}_{3}$, minor diastereomer) $\delta 146.7,128.4,126.2$, 86.0, 84.9, 52.9, 47.0, 43.7, 35.7, 33.1, 28.7, 27.5, 26.4, 24.3; IR (thin film) 3380, 2921, 1492, 1446, $1028 \mathrm{~cm}^{-1}$; HRMS (EI) $\mathrm{m} / \mathrm{z}$ calcd for $\mathrm{C}_{17} \mathrm{H}_{26} \mathrm{NO}(\mathrm{M}+\mathrm{H})^{+} 260.2014$, found 260.2003 . 
8,5-Bicyclic methylamine (34a, major):

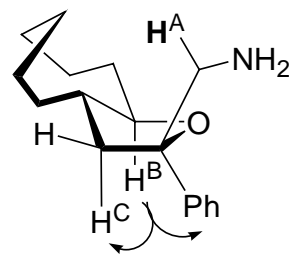

$34 a$

NOE experiments were performed for 34a using a pure sample of the isomer in $\mathrm{CDCl}_{3}$

$\mathbf{H}^{\mathbf{B}}$ irradiated: $\mathrm{Ph}(1.8 \%), \mathrm{H}^{\mathrm{C}}(1.2 \%)$

Note: The absence of an NOE between $\mathrm{H}^{\mathrm{A}}$ and $\mathrm{H}^{\mathrm{B}}$ along with the observation of an NOE between $\mathrm{H}^{\mathrm{B}}$ and phenyl suggest a 1,3-trans configuration.

\section{8,5-Bicyclic methylamine (34b, minor):}

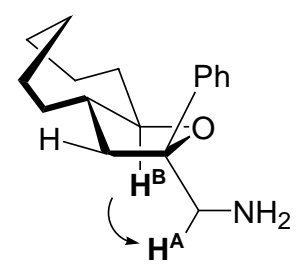

$34 b$

NOE experiments were performed for $\mathbf{3 4 b}$ using an 80:20 mixture of $\mathbf{3 4 a}$ and $\mathbf{3 4 \mathbf { b }}$ in $\mathrm{CD}_{3} \mathrm{OD}$

$\mathbf{H}^{\mathrm{B}}$ irradiated: $\mathrm{H}^{\mathrm{A}}(1.2 \%)$

Note: The observation of an NOE between $\mathrm{H}^{\mathrm{B}}$ and $\mathrm{H}^{\mathrm{A}}$ along with the absence of an NOE between $\mathrm{H}^{\mathrm{B}}$ and phenyl indicate the 1,3-cis configuration.

\section{References:}

(1) Pangborn, A. B.; Giardello, M. A.; Grubbs, R. H.; Rosen, R. K.; Timmers, F. J. Organometallics 1996, 15, 1518-1520.

(2) Romero, J. A. C.; Tabacco, S. A.; Woerpel, K. A. J. Am. Chem. Soc. 2000, 122, 168-169.

(3) Brown, H. C.; Prasad, J. V. N. V.; Zee, S.-H. J. Org. Chem. 1985, 50, 1582-1589.

(4) Anomeric ratio determined by ${ }^{1} \mathrm{H}$ NMR spectroscopy.

(5) Product diastereoselectivities determined by GC analysis of the unpurified reaction mixture and confirmed by ${ }^{1} \mathrm{H}$ NMR spectroscopy.

(6) Smith, D. M.; Tran, M. B.; Woerpel, K. A. J. Am. Chem. Soc. 2003, 125, 14149-14152.

(7) Smith, D. M.; Woerpel, K. A. Org. Lett. 2004, 6, 2063-2066.

(8) Smith, D. M.; Tran, M. B.; Woerpel, K. A. J. Am. Chem. Soc. 2003, 125, 14149-14152.

(9) Hu, Y.; Porko, J. A. J.; Labadie, J. W.; Gooding, O. W. J. Org. Chem. 1998, 63, 4518-4521.

(10) Missio, A.; Marchioro, C.; Rossi, T.; Panuzio, M.; Selca, S.; Seneci, P. Biotechnol. Bioeng. 1999, 71, 38-43.

(11) Doi, T.; Sugiki, M.; Yamada, H.; Takahashi, T.; Porko, J. A. J. Tetrahedron Lett. 1999, 40, $2141-2144$.

(12) Brown, H. C.; Toon, N. M. J. Am. Chem. Soc. 1966, 88, 1464-1472. 


\section{Analytical Data}

A. $\quad$ Selected ${ }^{1} \mathrm{H}$ NMR spectra

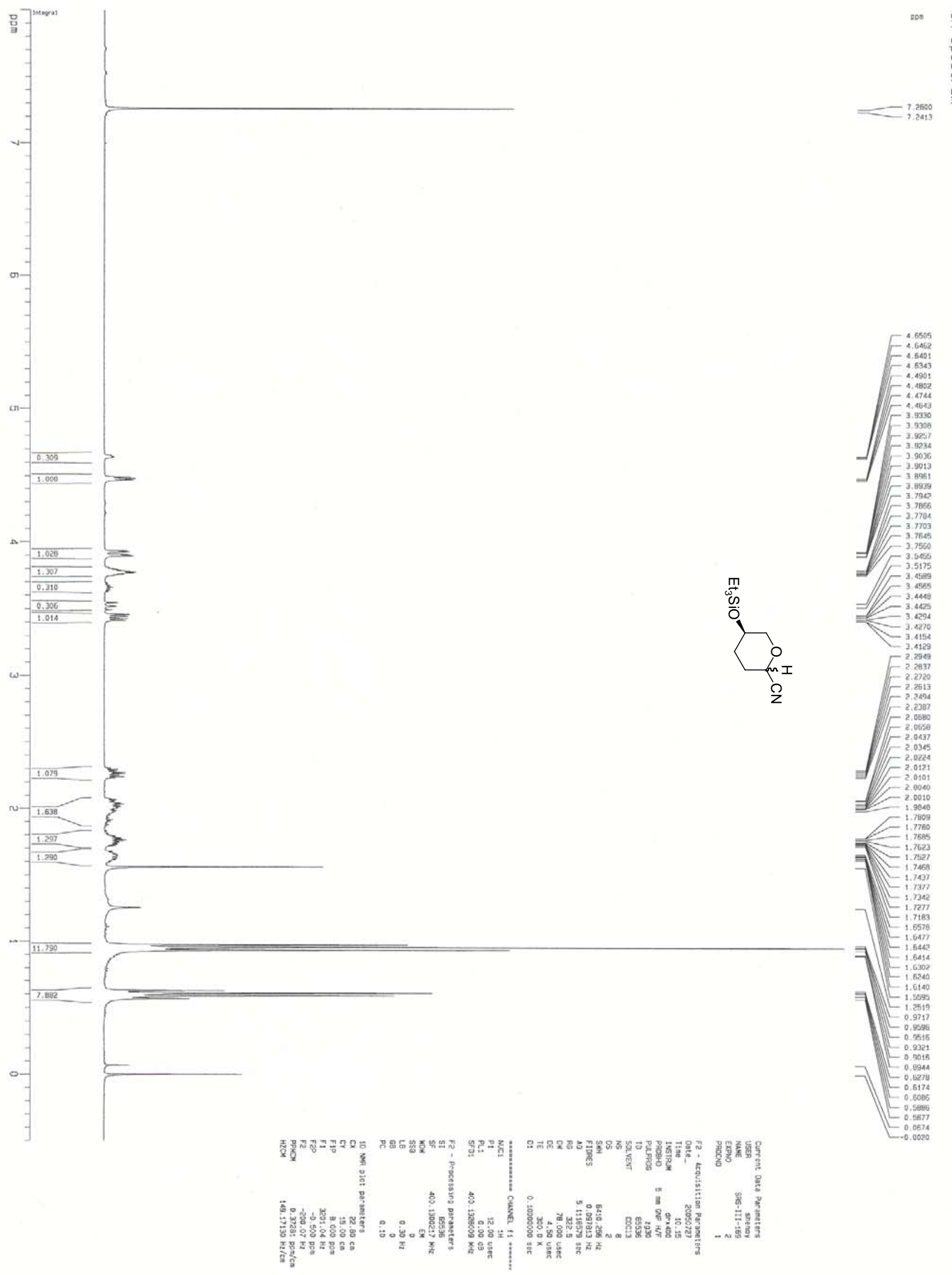




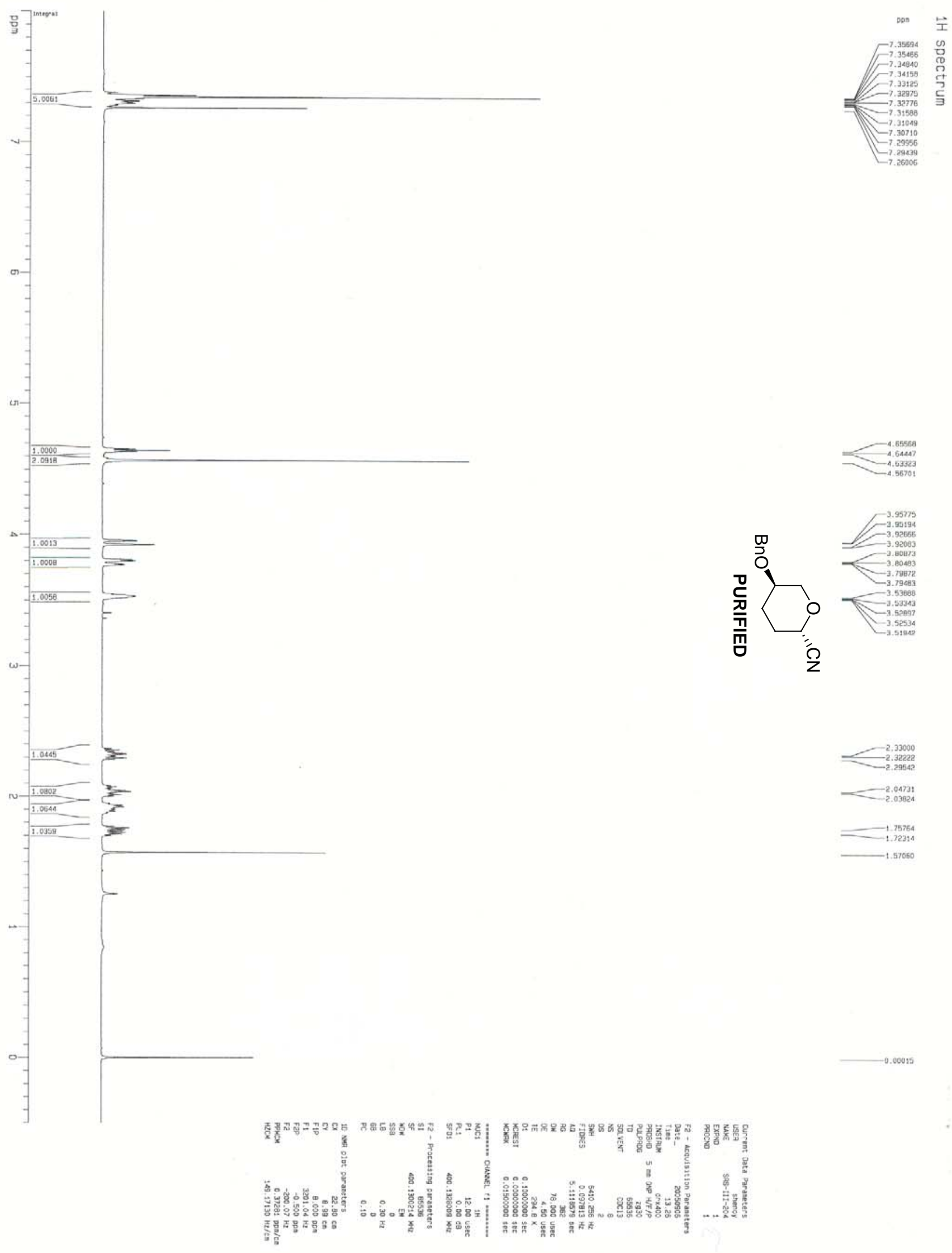




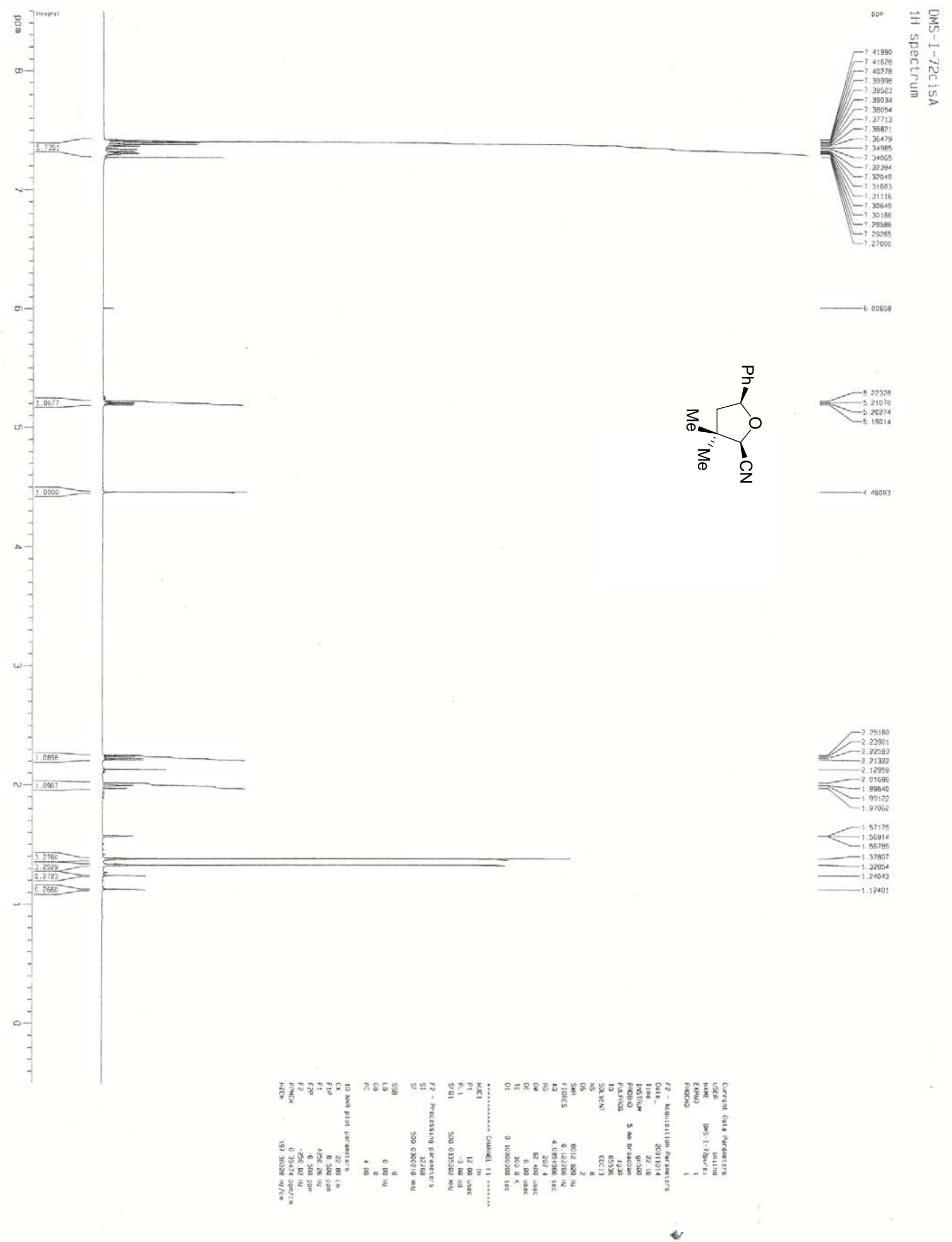




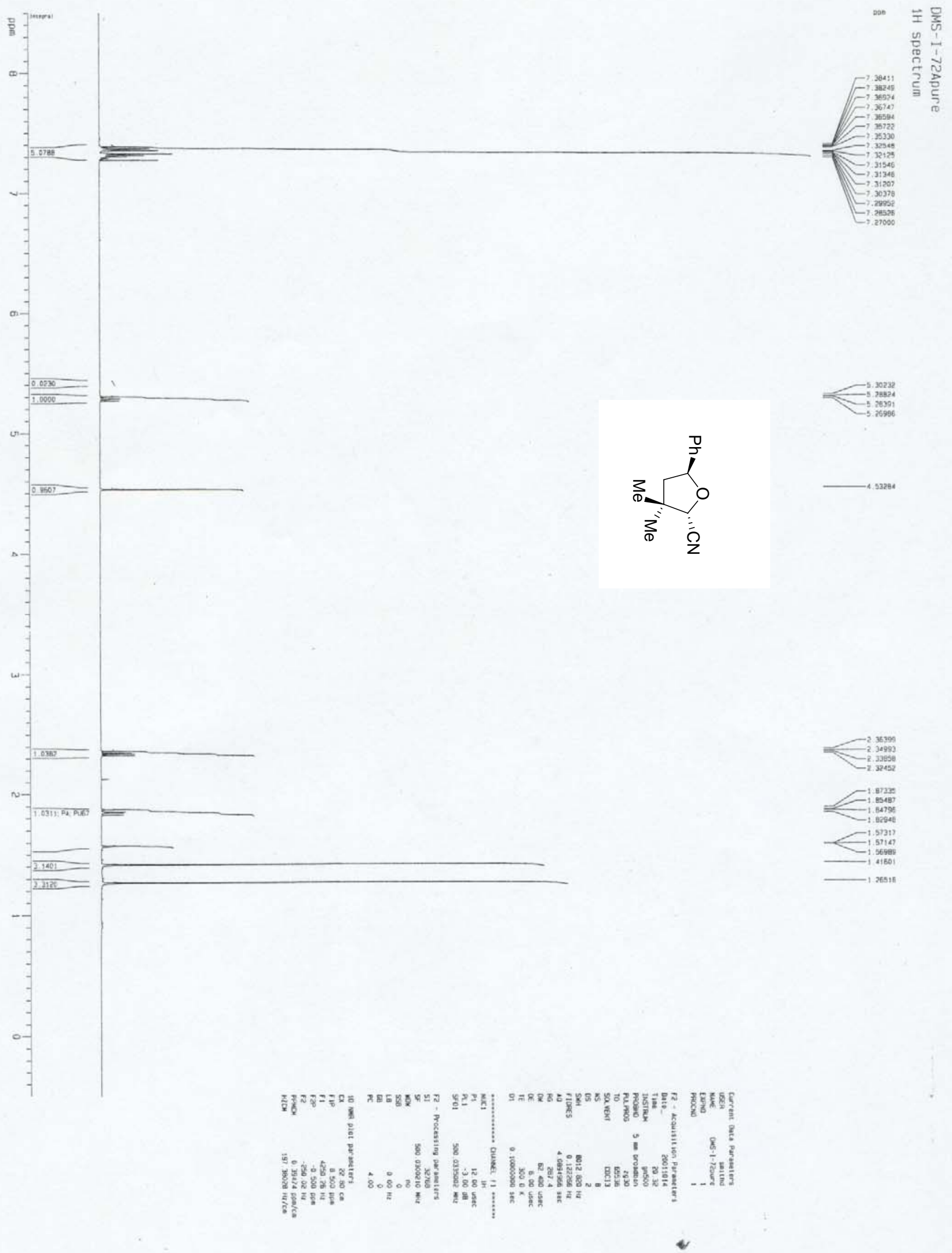




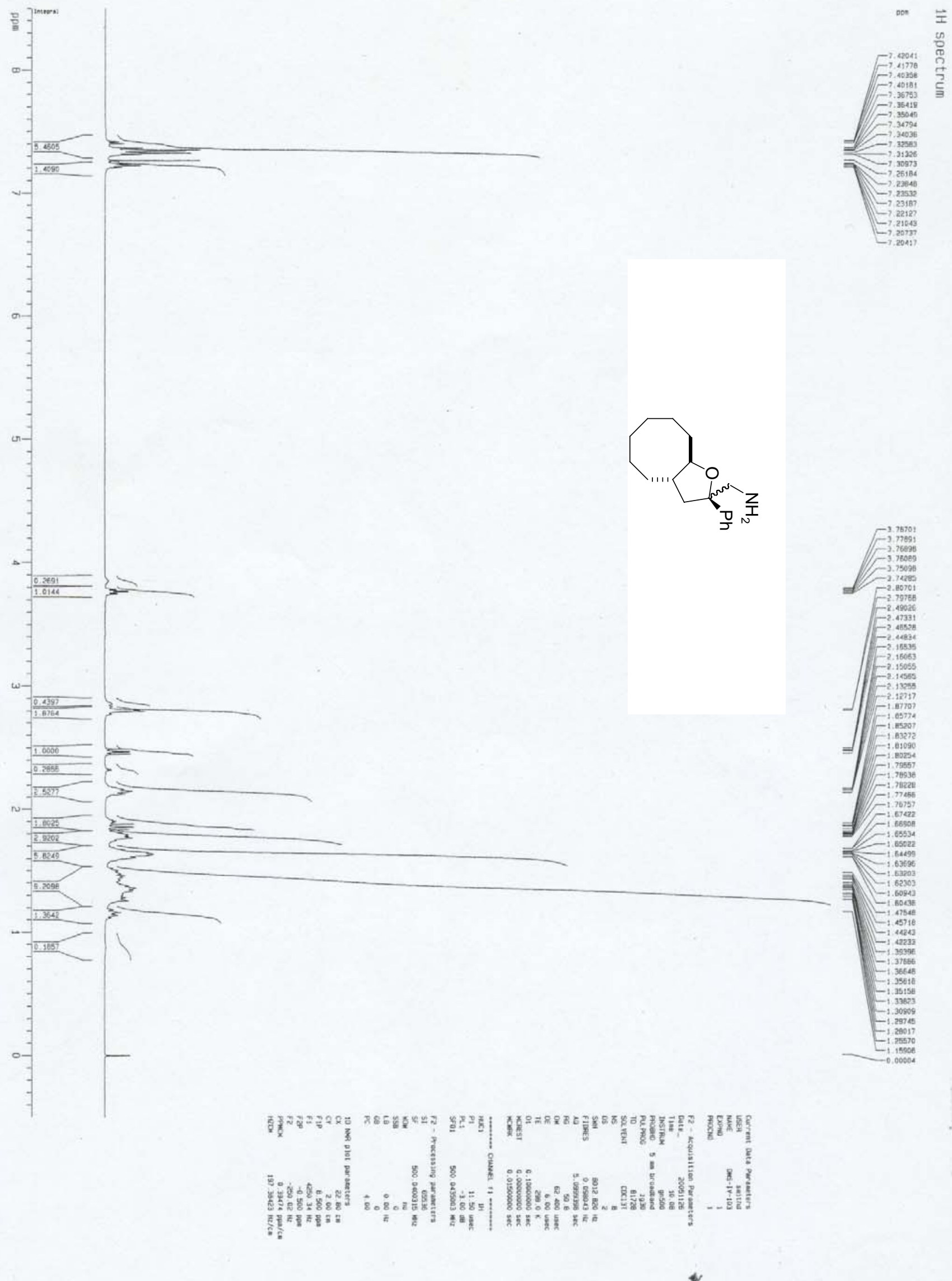


B. GC Chromatograms showing solvent effects on diastereoselectivity of $\mathrm{Me}_{3} \mathrm{SiCN}$ addition to acetal 1

SOLVENT: $\mathrm{CH}_{2} \mathrm{Cl}_{2}$

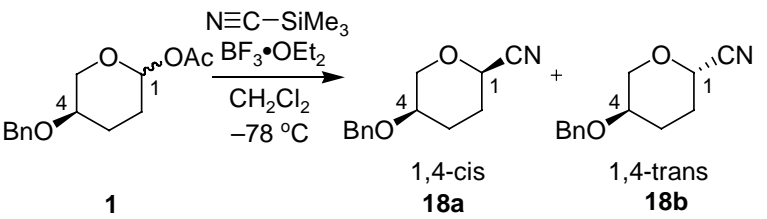

\begin{tabular}{|c|c|c|c|c|c|c|}
\hline eak & $\begin{array}{l}\text { RetTime } \\
\text { [min] }\end{array}$ & Sig & Type & $\begin{array}{r}\text { Area } \\
{\left[\mathrm{pA}^{*} \mathrm{~s}\right]}\end{array}$ & $\begin{array}{l}\text { Height } \\
\text { [pA] }\end{array}$ & $\begin{array}{c}\text { Area } \\
\frac{\circ}{6}\end{array}$ \\
\hline 1 & 0.711 & 1 & BV & 2.39308 & 6.75692 & 0.004 \\
\hline 2 & 0.7 & 1 & VV & 21.9 & 71.6 & \\
\hline 3 & 0.74 & 1 & VV S & $1.34756 \mathrm{e} 4$ & 4.4036 & 22.58 \\
\hline 4 & 0.763 & 1 & BV $\mathrm{T}$ & 1.9 & & \\
\hline 5 & 0.786 & 1 & VB $S$ & 4.60336 & 1.373 & 77.14 \\
\hline 6 & 0.861 & 1 & BV $x$ & 75.88 & 194 & \\
\hline 7 & 0.877 & 1 & VV $x$ & 1.645 & & 0.00276 \\
\hline 8 & 0.909 & 1 & VB $X$ & 2.64 & & 0.00444 \\
\hline 9 & 1.063 & 1 & VB $x$ & 20.0 & 39. & \\
\hline 10 & 5.852 & 1 & PB & 6.83322 & 3.44175 & 0.01145 \\
\hline 11 & 10.939 & & BV & 18.81050 & 8.96996 & 0.03152 \\
\hline & & & VB & & 4.08882 & 0.01624 \\
\hline
\end{tabular}

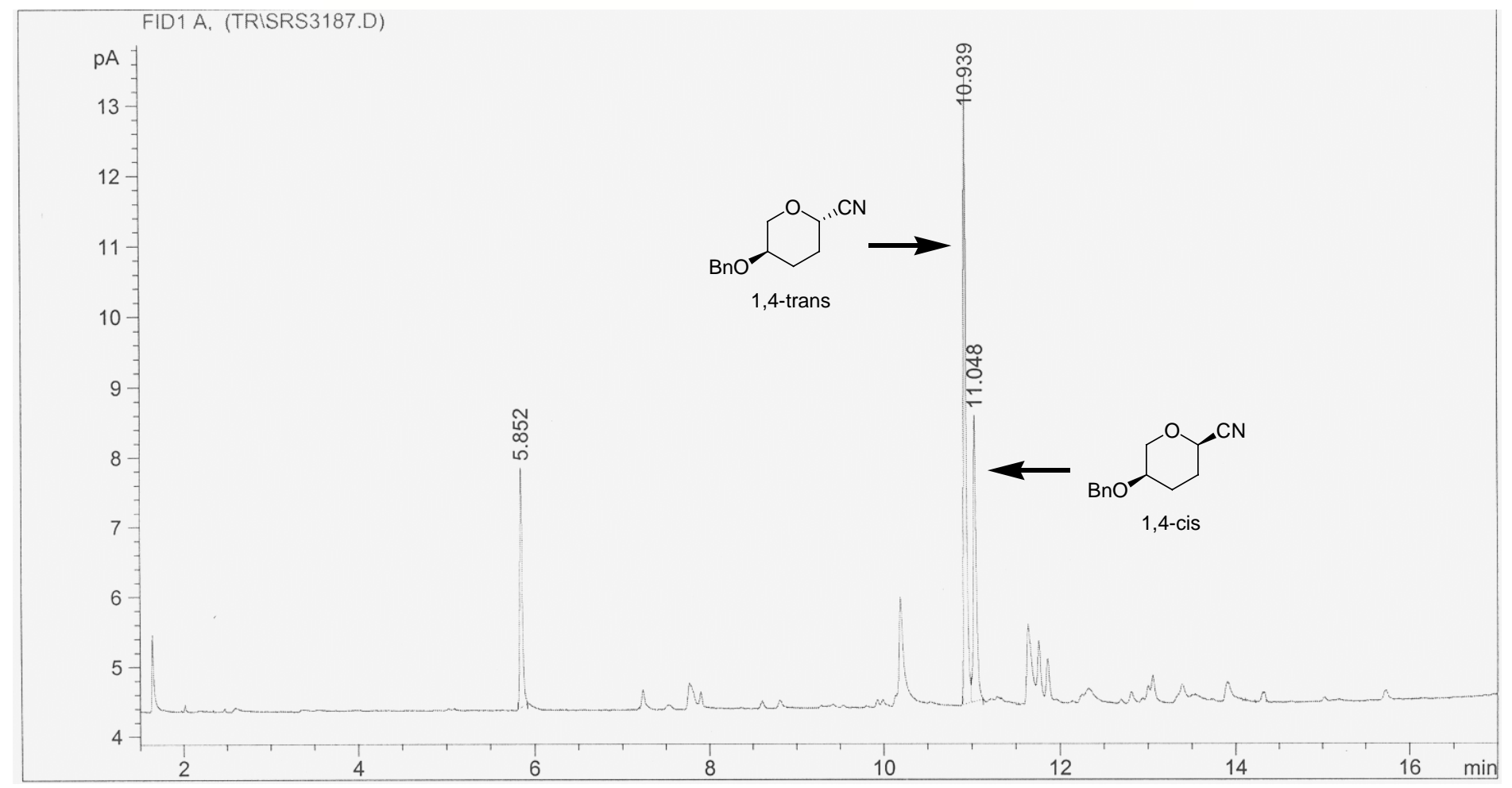




\section{SOLVENT: $\mathrm{CH}_{3} \mathrm{CN}$}

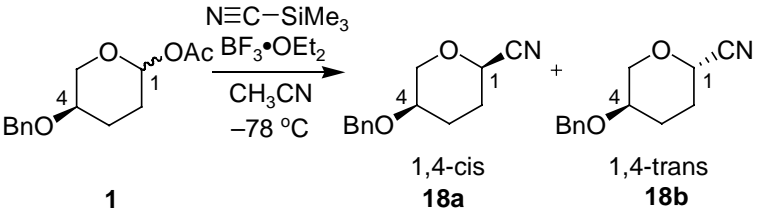

\begin{tabular}{|c|c|c|c|c|c|c|}
\hline $\begin{array}{l}\text { eak } \\
\#\end{array}$ & $\begin{array}{c}\text { RetTime } \\
\text { [min] }\end{array}$ & Sig & & $\begin{array}{r}\text { Area } \\
{\left[\mathrm{pA}^{*} \mathrm{~S}\right]}\end{array}$ & $\begin{array}{l}\text { Height } \\
{[\mathrm{pA}]}\end{array}$ & $\begin{array}{c}\text { Area } \\
\frac{\circ}{8}\end{array}$ \\
\hline & & & & & & \\
\hline 1 & 0.710 & 1 & PV & 17.86762 & 48.98180 & 0.01464 \\
\hline 2 & & 1 & VV S & 3734.31348 & $1.11573 \mathrm{e} 4$ & 3.06000 \\
\hline 3 & 0 & 1 & VV S & 4.692 & $1.37927 e 5$ & 38.45040 \\
\hline 4 & 0 & 1 & BV $\mathrm{X}$ & 99 & 162.5332 & 0.08 \\
\hline 5 & .786 & 1 & VB $S$ & $7.11347 \mathrm{e}$ & $1.65999 \mathrm{e} 5$ & 58.28985 \\
\hline 6 & .862 & 1 & $B V X$ & 51.7 & 110.6374 & 0.04 \\
\hline 7 & .8 & 1 & VV $\mathrm{X}$ & 2.1 & 4. 4 & 0.00 \\
\hline 8 & 0.910 & 1 & VB $X$ & 3.66141 & 7.25203 & 0.00 \\
\hline 9 & 1.065 & 1 & VB & 26.69479 & 45.08500 & 0.02187 \\
\hline 10 & 1.651 & 1 & PB & 7.85139 & 5.21629 & 0.00643 \\
\hline 11 & 10.941 & 1 & MM & 33.19231 & 17.67716 & 0.0272 \\
\hline 12 & 11.047 & 1 & MM & $9.67778 e-1$ & $8.34230 e-1$ & $0.0007 \mathrm{~s}$ \\
\hline
\end{tabular}

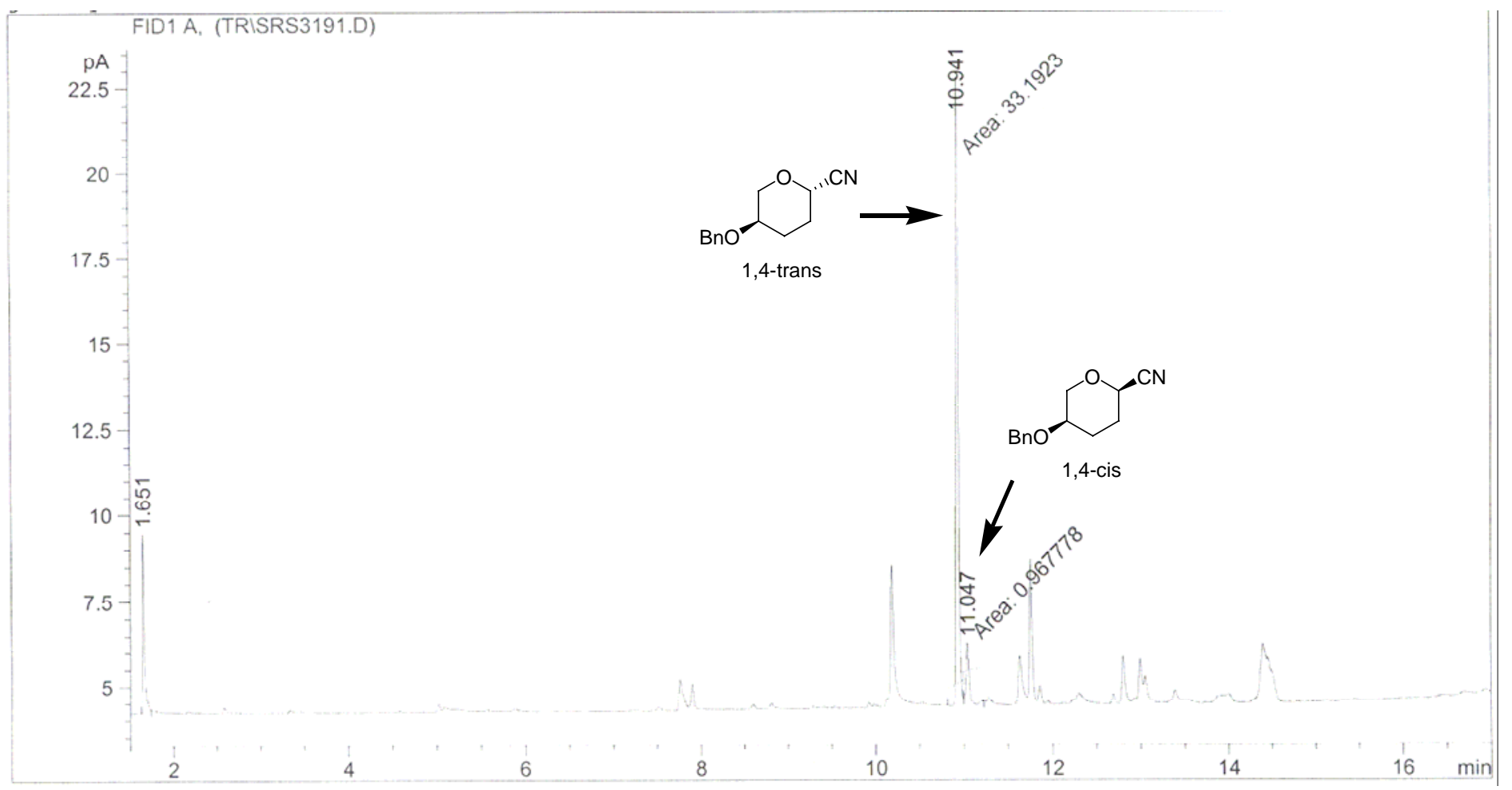


C. IR spectra of three-phase test and control experiments

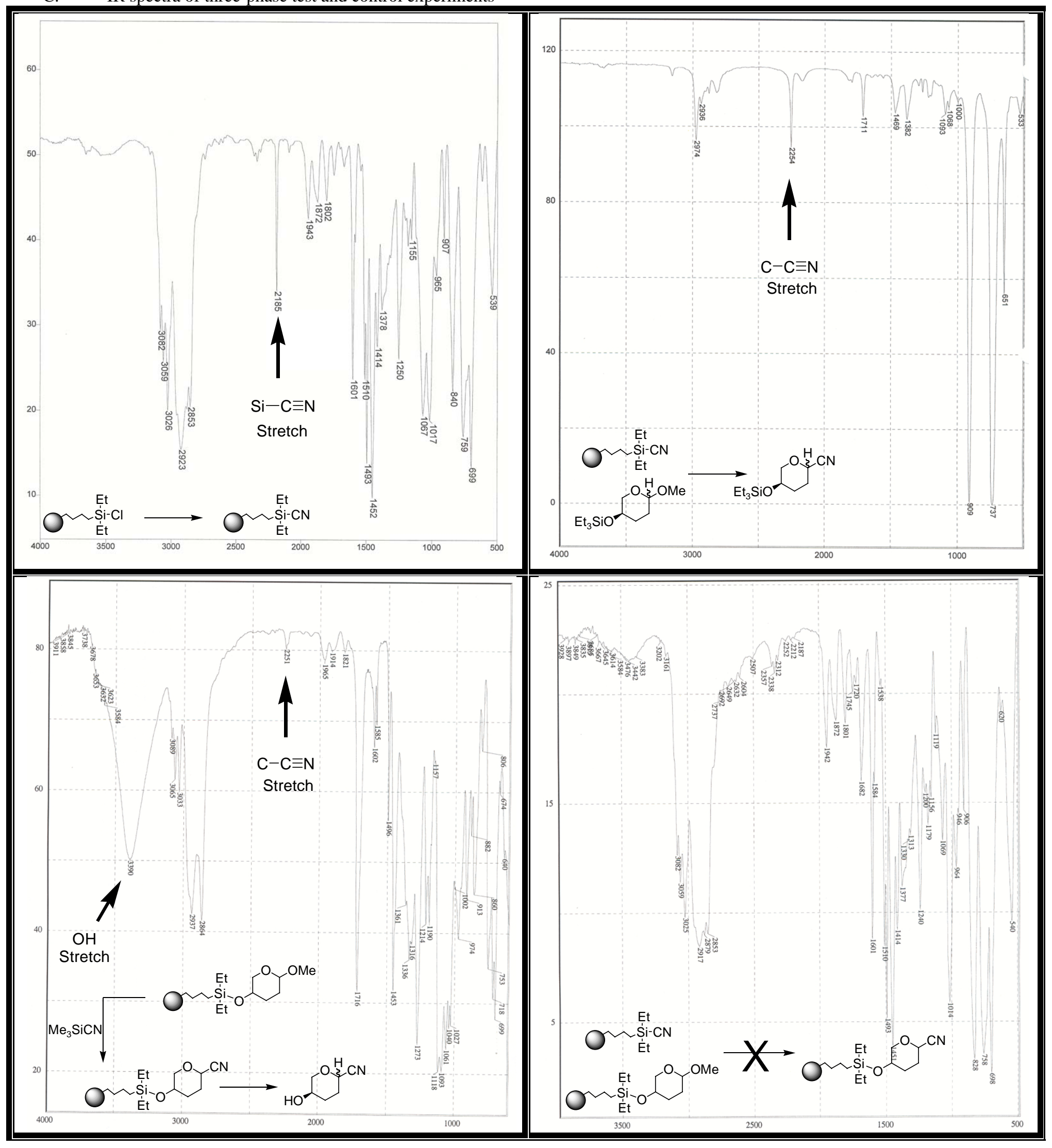


D. GC Chromatograms of competition experiments

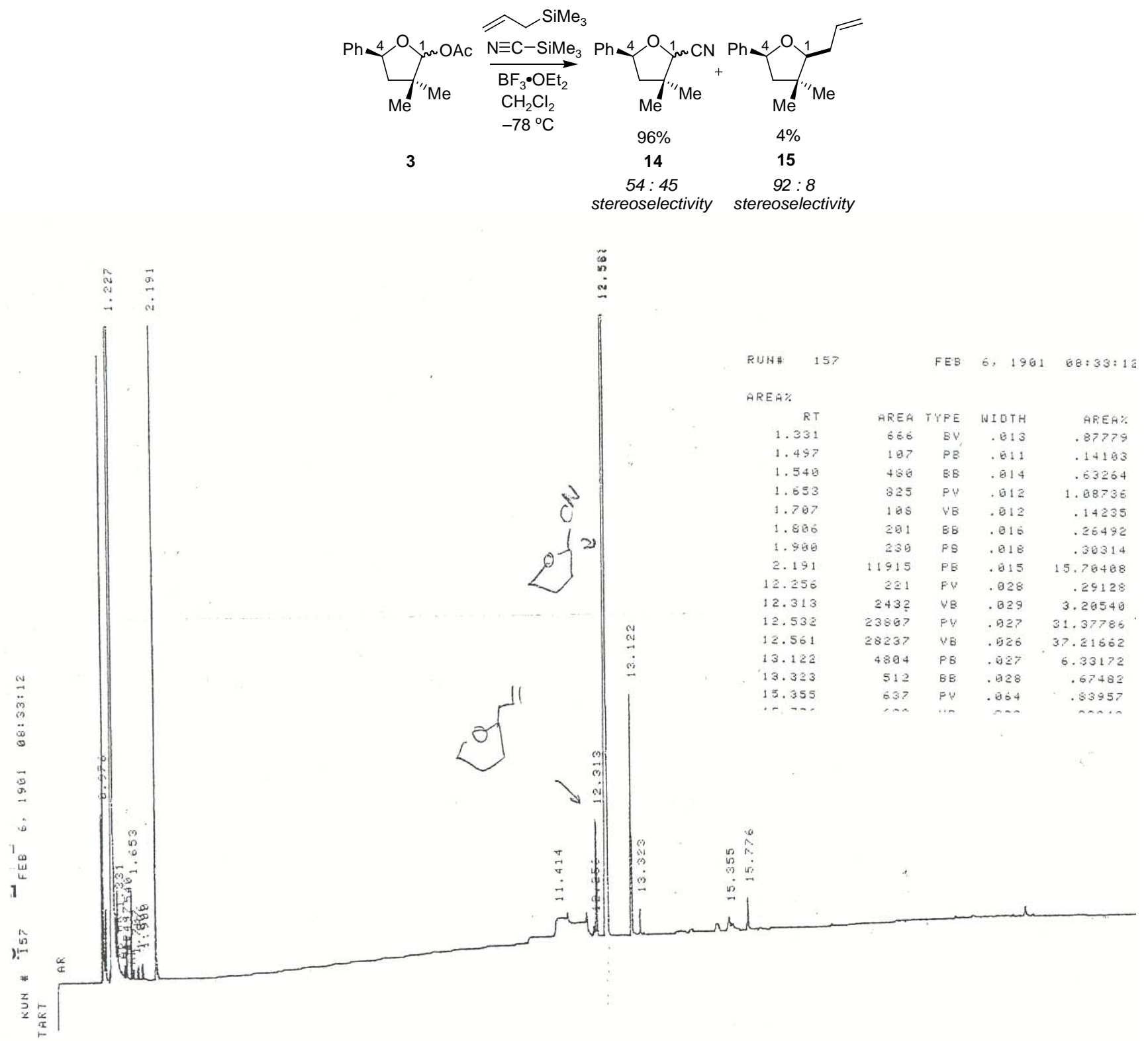



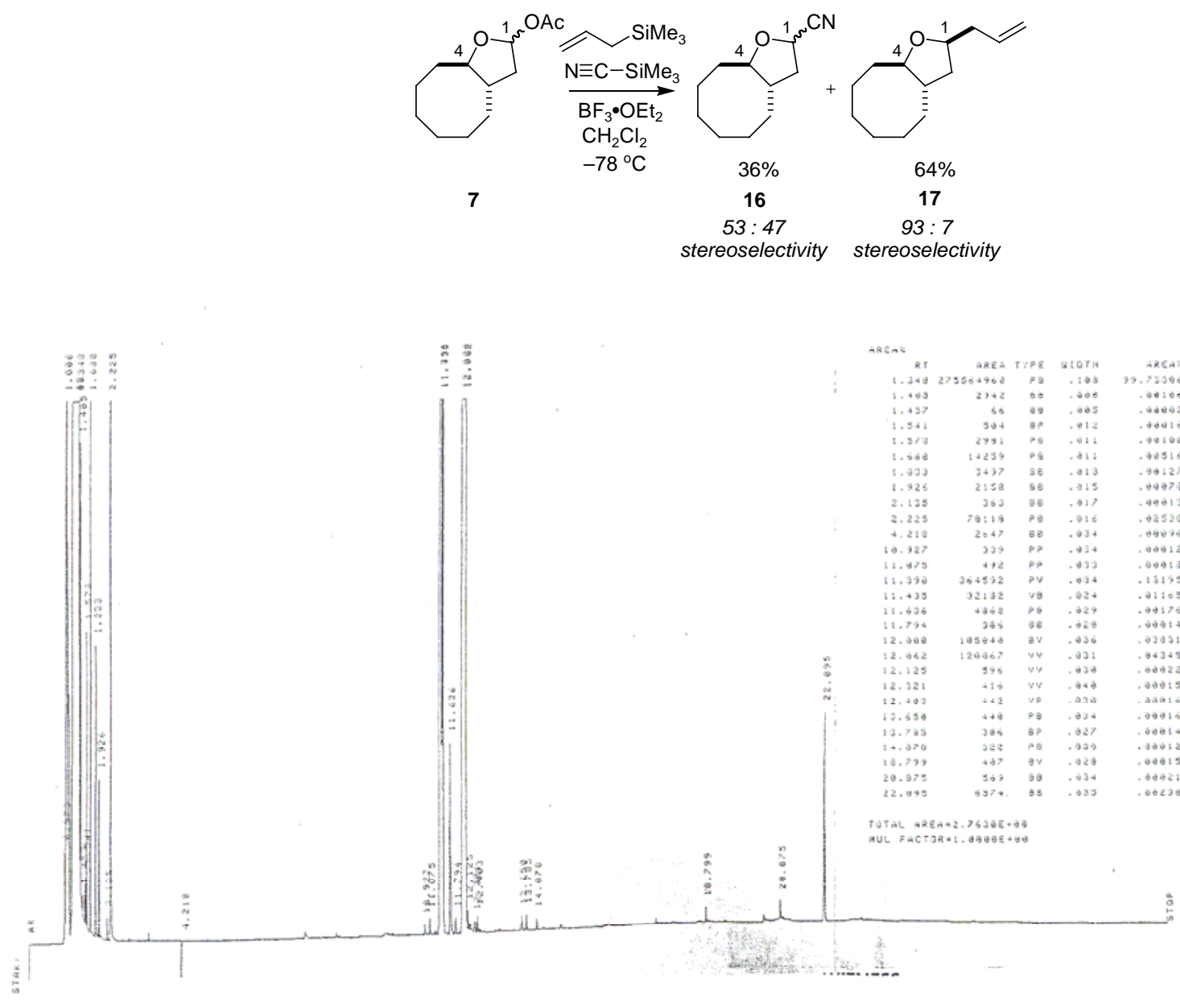

crude:

allyl $(92: 4)$

nitrib: $(47: 53)$

led to Page

$64 \%$

DATE alfyl/nit 


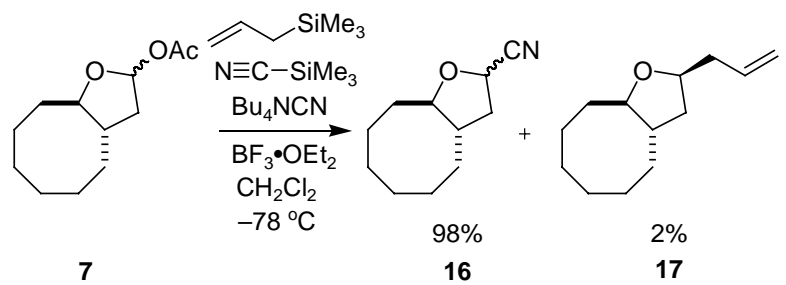

\begin{tabular}{|c|c|c|c|c|c|c|}
\hline Peak & RetTime & Type & $\begin{array}{l}\text { Width } \\
\text { [min] }\end{array}$ & $\begin{array}{r}\text { Area } \\
{\left[\mathrm{pA}{ }^{*} \mathrm{~s}\right]}\end{array}$ & $\begin{array}{l}\text { Height } \\
{[\mathrm{pA}]}\end{array}$ & $\begin{array}{c}\text { Area } \\
\frac{\circ}{6}\end{array}$ \\
\hline & & & $-\ldots-$. & $\ldots \ldots \ldots$ & $-\cdots \cdots \cdots$ & $\cdots \cdots-\cdots$ \\
\hline 1 & 6.885 & $\mathrm{~PB}$ & 0.3327 & 47.22771 & 2.05084 & 7.72499 \\
\hline 2 & 10.431 & MM & 0.0000 & 13.68676 & $3.42975 e-1$ & 2.23873 \\
\hline 3 & 11.002 & MM & 0.2647 & 550.44849 & 34.65651 & 90.03628 \\
\hline
\end{tabular}

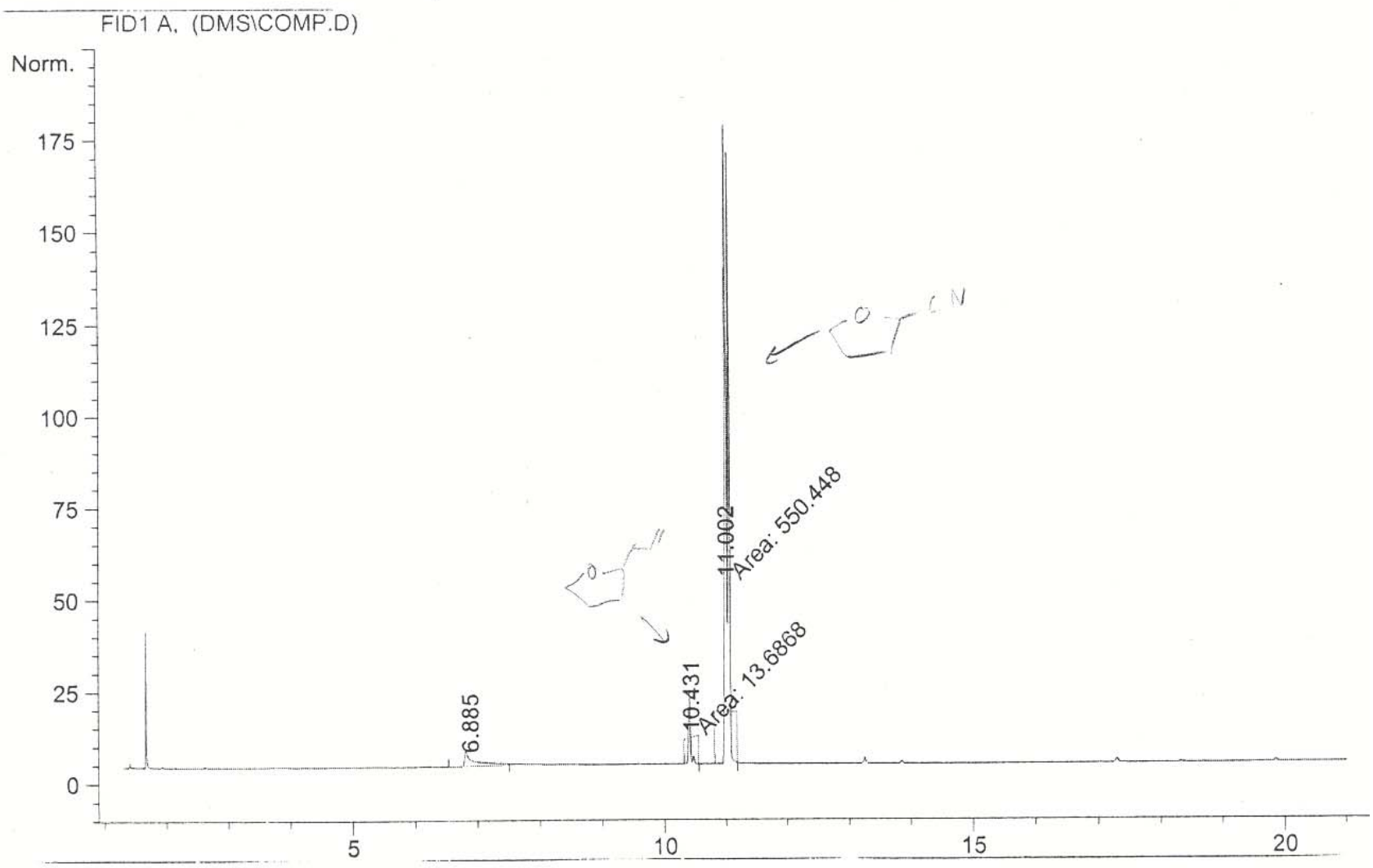




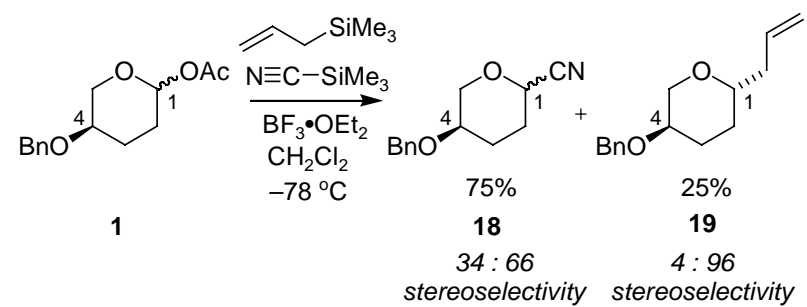

\begin{tabular}{|c|c|c|c|c|c|c|}
\hline $\begin{array}{c}\text { Peak } \\
\#\end{array}$ & $\begin{array}{l}\text { RetTime } \\
\text { [min] }\end{array}$ & Type & $\begin{array}{c}\text { Width } \\
\text { [min] }\end{array}$ & $\begin{array}{r}\text { Area } \\
{\left[\mathrm{pA}{ }^{*} \mathrm{~s}\right]}\end{array}$ & $\begin{array}{l}\text { Height } \\
{[\mathrm{pA}]}\end{array}$ & $\begin{array}{c}\text { Area } \\
\%\end{array}$ \\
\hline & & & & -------- & 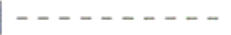 & $----\cdot-$ \\
\hline 15 & 1.415 & BP & 0.0120 & $2.17338 e-1$ & $2.81905 e-1$ & 0.00064 \\
\hline 16 & 1.676 & PB & 0.0139 & 6.03119 & 6.75557 & 0.01779 \\
\hline 17 & 7.414 & PB & 0.0293 & $5.11163 e-1$ & $2.18734 \mathrm{e}-1$ & 0.00151 \\
\hline 18 & 8.519 & $\mathrm{BB}$ & 0.0333 & $5.73287 e-1$ & $2.05351 e-1$ & 0.00169 \\
\hline 19 & 9.730 & $\mathrm{~PB}$ & 0.0458 & 3.79024 & 1.02618 & 0.01118 \\
\hline 20 & 10.710 & PB & 0.0298 & 17.51391 & 7.47903 & 0.05166 \\
\hline 21 & 11.204 & PB & 0.0305 & $7.20832 e-1$ & $2.85204 e-1$ & 0.00213 \\
\hline 22 & 11.329 & PP & 0.0282 & $4.17282 e-1$ & $1.77383 e-1$ & 0.00123 \\
\hline 23 & 13.024 & BP & 0.0140 & 12.73261 & 14.51267 & 0.03755 \\
\hline 24 & 13.086 & VV & 0.0142 & 177.10429 & 202.08122 & 0.52236 \\
\hline 25 & 13.146 & VV & 0.0134 & 373.10806 & 419.61047 & 1.10045 \\
\hline 26 & 13.183 & VV & 0.0128 & 210.30008 & 262.47064 & 0.62026 \\
\hline
\end{tabular}

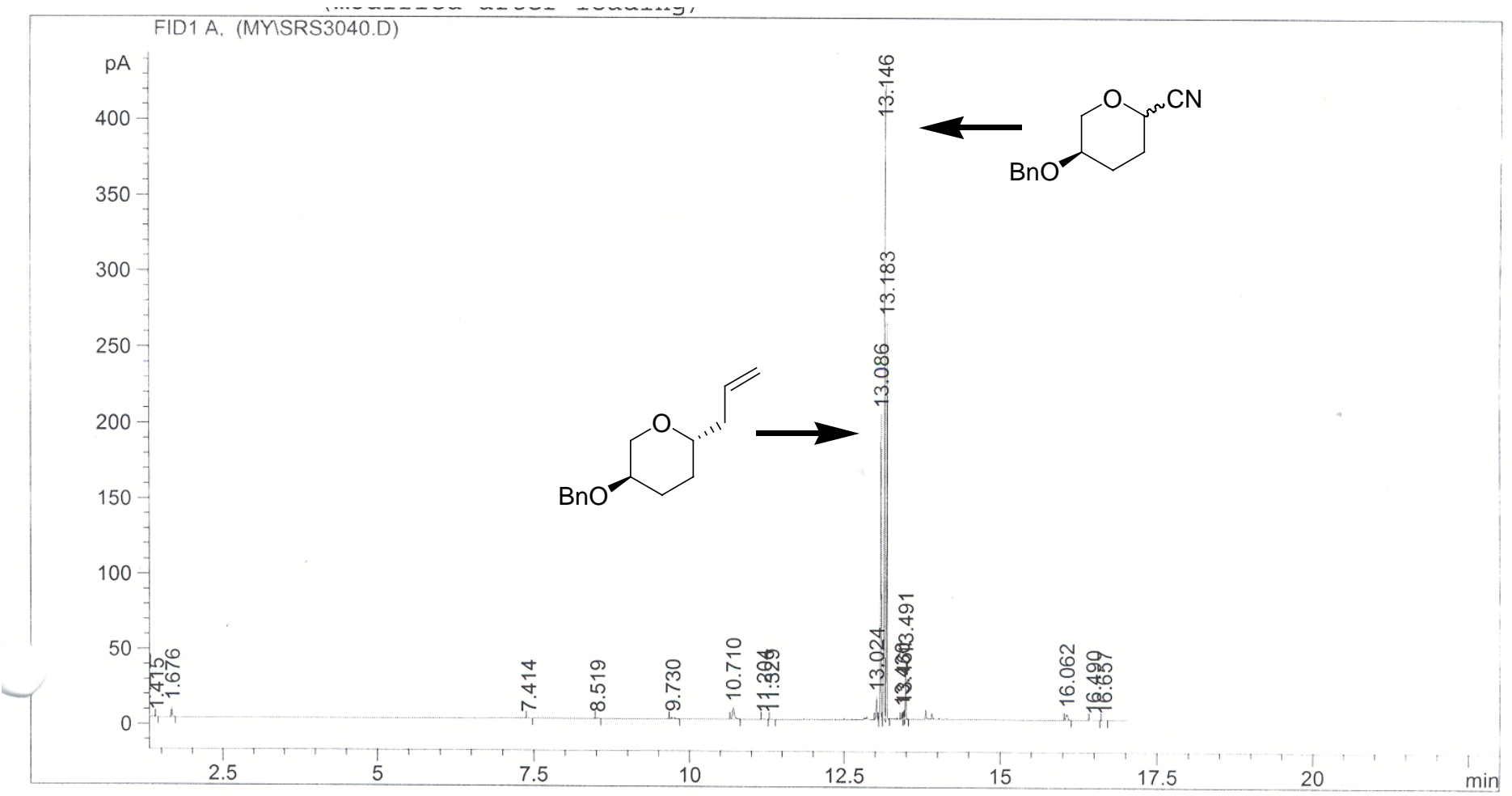




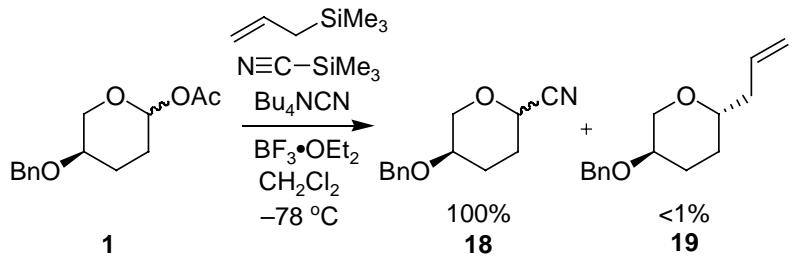

\begin{tabular}{|c|c|c|c|c|c|c|}
\hline $\begin{array}{c}\text { Peak } \\
\#\end{array}$ & $\begin{array}{c}\text { RetTime } \\
\text { [min] }\end{array}$ & Type & $\begin{array}{l}\text { Width } \\
\text { [min] }\end{array}$ & $\begin{array}{r}\text { Area } \\
{\left[\mathrm{pA}{ }^{*} \mathrm{~s}\right]}\end{array}$ & $\begin{array}{l}\text { Height } \\
{[\mathrm{pA}]}\end{array}$ & $\begin{array}{c}\text { Area } \\
\frac{\circ}{6}\end{array}$ \\
\hline & & & & --------- & 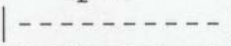 & ---- \\
\hline 1 & 1.316 & BP & 0.0144 & 1. $36283 e-1$ & $1.20616 \mathrm{e}-1$ & 0.04 \\
\hline 2 & 1.415 & PP & 0.0145 & $2.38260 e-1$ & $2.37019 e-1$ & 0.08657 \\
\hline 3 & 1.472 & $\mathrm{~PB}$ & 0171 & $2.83918 e-1$ & $2.52377 e-1$ & 0.10316 \\
\hline 4 & 7.748 & VB & 0.0309 & 18.54024 & 7.61317 & 6.7 \\
\hline 5 & 9.040 & BB & 0.0264 & 10.53622 & 4.88426 & 3.82811 \\
\hline 6 & 10.644 & BP & 0.0244 & $5.14713 e-1$ & $2.67936 e-1$ & 0.18701 \\
\hline 7 & 10.801 & $\mathrm{BP}$ & 0.0236 & 6.27152 & 3.23260 & 2.27862 \\
\hline 8 & 10.941 & BV & 0.0243 & 160.24129 & 81.15934 & 58.22016 \\
\hline 9 & 11.042 & VV & 0.0297 & 61.86851 & 28.05285 & 22.47857 \\
\hline
\end{tabular}

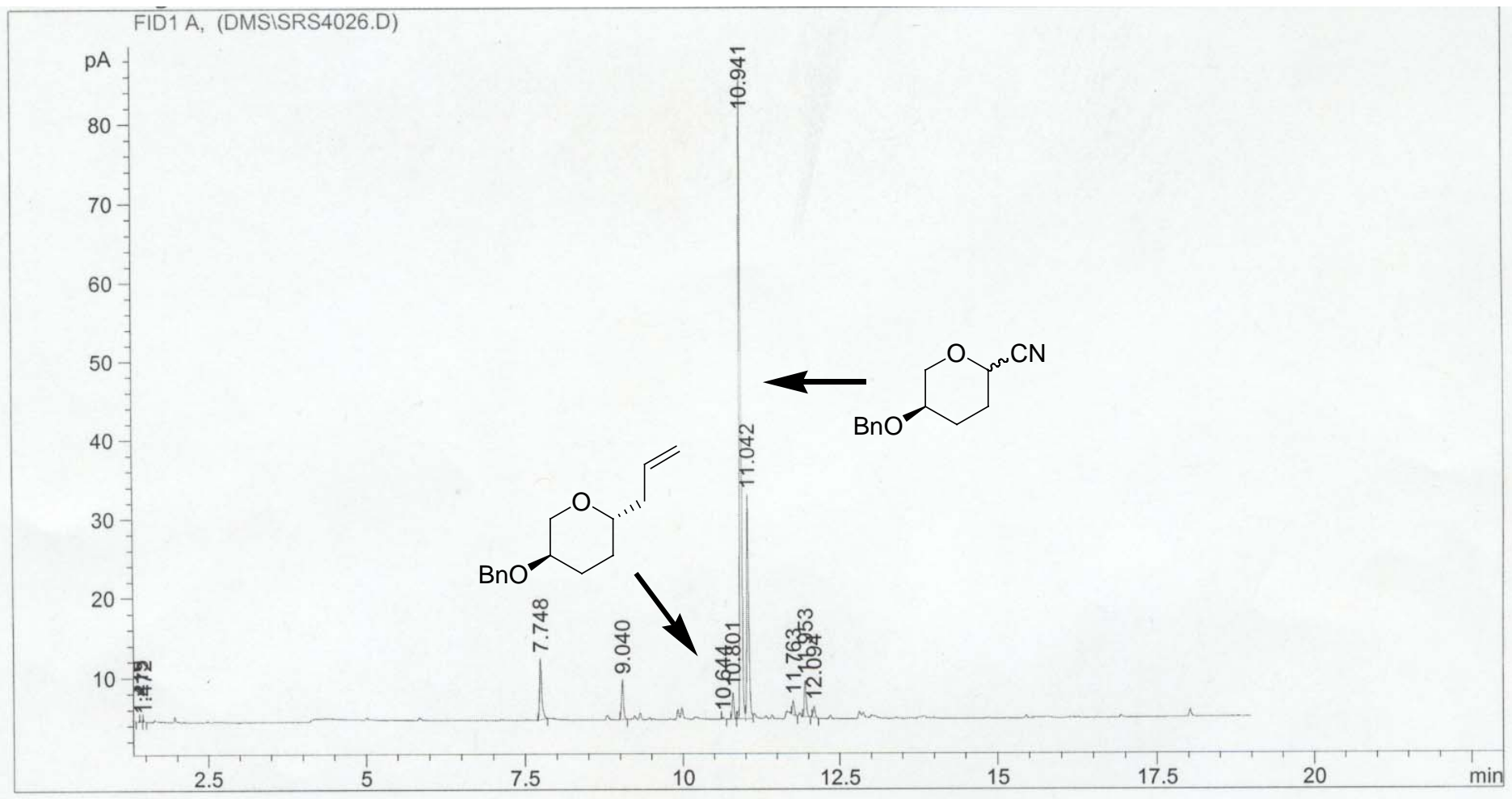

